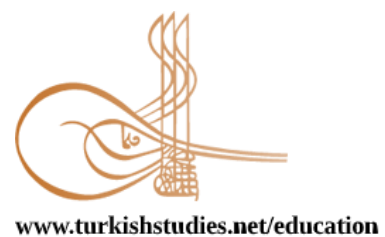

Turkish Studies - Educational Sciences

Research Article / Araştırma Makalesi

\title{
TBMM Milletvekillerinin Türk Eğitim Politikalarına Yönelik Algılarının İncelenmesi*
}

\author{
Investigation of TBMM Representatives' Perceptions of Turkish Education Policies
}

\author{
İsmail Erol $^{* *}-$ Münevver Çetin ${ }^{* * *}$
}

\begin{abstract}
Representatives have broad authority in the establishment of Turkish education policies. With the globalization in the world, it is important for elected representatives to be able to determine long-term education policies appropriate to modern philosophies and technology besides meeting with the needs of the society in this direction. For this reason, education, training and management policies are included in the codes and programs of political parties. The aim of this research is to reveal the opinions of the representatives about Turkish education policies. Answers were sought for the questions reflecting cultural and moral values of Turkish education curriculum about the reflection of international exam results on Turkish education policies; training of teachers in Turkey; policy making regarding employment and qualifications; employment of school administrators. Maximum variation sampling method was employed for choosing study group. Five representatives participated in the research which is designed in phenomenology. Semi-structured interview form developed by the researcher was used to collect the data. The findings of the research are related to international exams: the improvement of educational policies, conditional acceptance and the importance of international exams; regarding teacher training policies: qualitative problems, formation, ideological and theoretical orientations; employment of teachers: decrease in academic success, balance of supply and demand and not to feel cultural belonging; employment processes of managers: the importance of merit, the need for postgraduate education and trade union negativities; reflection of the curriculum on the values: insufficiency of the curriculum, application deficiencies and cultural erosion.
\end{abstract}

Structured Abstract: Educational policies have increased their importance in accordance with science in the globalizing world, modern thought systems and the use of technology in every field. At the same time, these educational policies have contributed more to social life and the opening of schools where all sectors are trained, with the value of industrialization and development in the national and international arena through inclusion of large masses. It is known that political parties and politicians are also involved in education and training policies. Özsoy (2012) states that as for politicians, education is "a strategic battlefield of political competition". Therefore, "who will learn what and how much" is determined by community power

\footnotetext{
* $\mathrm{Bu}$ araştırma İsmail Erol tarafından Marmara Üniversitesi Eğitim Bilimleri Enstitüsünde Münevver Çetin danışmanlığında yürütülmekte olan "Yasama Erkinin Türk Eğitim Sistemi Yönetimine İlişkin Görüşlerinin İncelenmesi" isimli doktora tezinin pilot araştırma sorularından üretilmiştir. Veriler 2018 yılında elde edilmiştir.

** Öğr. Gör., Namık Kemal Üniversitesi, Sağlık Hizmetleri Meslek Yüksek Okulu, Çocuk Gelişimi Bölümü Lec., Namık Kemal University, Vocational School of Health Services, Child Development Program ORCID 0000-0001-8531-6001

ismailerol59@hotmail.com

**** Prof. Dr., Marmara Üniversitesi, Eğitim Fakültesi, Eğitim Bilimleri Bölümü

Prof., Marmara University, Faculty of Education, Department of Educational Sciences

ORCID 0000-0002-1203-9098

Cite as/ Atıf: Erol, E. \& Çetin, M. (2020). TBMM milletvekillerinin Türk eğitim politikalarına yönelik algılarının incelenmesi, Turkish Studies - Education, 15(3), 1829-1856. https://dx.doi.org/10.29228/TurkishStudies.43336

Received/Geliş: 03 May/Mayıs 2020

Accepted/Kabul: 20 June/Haziran 2020

Checked by plagiarism software

Copyright (C) INTAC LTD, Turkey

Published/Yayin: 25 June/Haziran 2020

CC BY-NC 4.0
} 
relationship. Thus, the discussions carried out on educational policies are not simple arguments but they are clashing of political powers and reference paradigms. Educational systems in our age are planned and implemented as a policy of the public. As a short description of education policies, it is the whole of the rules, laws and principles that are brought out regarding the management of school and education systems. The establishment of educational policies is managed by central government, local government, or local government systems or in unity according to the political system in the countries. Unfortunately, as a result of constantly changing political administrations in Turkey and the educational policies that are changed and developed by each new government, it could not be possible to develop a domestic and national system. One of the weaknesses of the educational policies enacted by lawmakers in Turkey is the failure to provide stability in this policy. For example, a constant change is the matter within the context of international exams' results and the process of harmonization with the European Union, the status of cultural and moral values in the education curriculum, the training of teachers and the employment process, the appointment of educational administrators and qualification. What are the paradigms underlying these changes? This is difficult to understand and requires a process. The changes put into practice cause losses of time, labor and material due to the large and broad structure of the Turkish education system. So, what is the perception of the deputies who have the legislative power to overcome these policy-making problems in education? It is important for the country to reveal these perceptions. Considering the limited number of studies examining the perceptions of deputies about education policies, the purpose of this research is determined as "examining the perceptions of the deputies who have legislative power towards Turkish education policies"

A "qualitative method" was used in order to examine the Turkish Grand National Assembly (TGNA) deputies' perceptions of Turkish education policies within the scope of the research. Today, qualitative studies are directed to obtain detailed information about education and to reduce the limitations in quantitative research. The research was designed in accordance with the "phenomenology" pattern, which is one of the qualitative research patterns. Phenomenology pattern is a qualitative pattern in which the researcher aims to reveal his perceptions, experiences and reactions towards a particular phenomenon (Fraenkel, Wallen \& Hyun, 2012). The study group of the study was formed by "maximum variation sampling from non-probabilistic sampling types". In maximum variation sampling, it is aimed to examine all situations that show variations in explaining a case (Patton, 2002). Accordingly, a semi-structured meeting was held with 5 deputies, who were members of the Turkish Grand National Assembly and belonged to different political parties. The principle of volunteering was taken into account in participating in the research. The data were collected by "semi-structured interview forms" developed by the researcher. It is emphasized that "semi-structured interviews" consisting questions related to the subject to be explored is the most common form of data collection in interview methods. While writing the interview form, the body of literature has been examined and presented to 4 experts in education management and supervision and 1 expert in measurement and evaluation area for evaluation and comprehensiveness. The interview form has taken its final form according to the feedbacks received. Members of the Turkish Grand National Assembly (TGNA) who will participate in the meeting have been previously informed about the subject of the research. The interview process has been carried out by taking voice recording in accordance with the permission of the participants. In cases where sound recording is not required, detailed notes have been kept. Information indicating where the interviews will take place and how long it will take is recorded. The meetings took place between 21.05.2018 and 25.06.2018, the majority of which took place in the province of Ankara (3/5) and some of them were held in the provinces where the deputies $(2 / 5)$ were present. Considering the interview periods, interviews took place between 26 minutes and 71 minutes on average. The data collected through sound recording was turned into a written transcript. In the data analysis process of the research, "content analysis" method was used. First of all, 5 interview documents were transferred to the computer. As a result of the interviews, 21 page interview documents were obtained. 5 interview documents were recorded with deputy codes (M1, M2, M3, M4, M5). The documents obtained later were edited with MAXQDA 2018 software. Then, the documents obtained were edited with MAXQDA 2018 software. For the analysis of the data, the documents were examined within the scope of the research questions by repeatedly reading and paying attention to each detail. The data obtained were given systematically in the findings section according to the research questions and supported by direct quotations. In the process of research from the development of the data collection tools of the research to writing the results of the data analysis 5 experts of educational sciences were consulted. In this context, the frequency information of the data obtained, the demographic information and number of the participants, the direct quotations, the participant codes and the conceptual categories were tried to be presented in detail.

Turkish Studies - Education, 15(3) 
The findings obtained as a result of analyzing the data in the research have been presented in 5 subthemes created from the codes under the main theme of "Turkish Education Policies". Findings obtained as a result of data analysis have been explained in the form of theme, sub-theme and codes. These sub-themes are teacher training policies, international exams, teachers' employment policies, executive employment policies, and reflection of the curriculum on national values. The sub-theme of teacher training policies include qualitative problems, formation, ideological and theoretical orientations; sub-theme of international exams include improving education policies, conditional acceptance and the importance of international exams; The sub-theme of teachers' employment policies include the decrease in academic success, the balance of supply and demand and lack of cultural belonging; The sub-theme of employment processes of managers include the importance of qualification, the need for postgraduate education and union negativities; The sub-theme of curriculum reflection on values also includes inadequate curriculum, implementation deficiencies and cultural erosion; Turkish Grand National Assembly have undoubtedly the biggest power in determining Turkish Educational policy, planning of short- and long-term goals with this policy and ensuring continuity of these goals in the education system. For this reason, it is seen that perceptions of the deputies' about Turkish education policies lead the management of education system. When the research findings are examined, it turns out that the opinions of the TGNA deputies differ according to their membership of the government and opposition parties. This situation is the indicator that parliamentary deputies prioritize the ideologies of the political parties that they are involved more than their own personal views. When the research findings are examined; it is revealed that the opinions of the TGNA deputies differ according to their membership of the government and opposition parties. I8n the current study, Turkish educational policies as a result of the perceptions of the parliamentary deputies teacher training policies are associated with international exams, teachers 'employment policies, administrators' employment policies, and reflection of national values in the curriculum. As a consequence, it is concluded that the majority of TGNA deputies hopeful in establishing qualified Turkish education policies, but there are still elements that need to be improved in our education system. Especially in the political discourses of the deputies, they care about the interests of the country in the context of Turkish education policies, protect the interests of the citizens and care about the expectations of the youth from education.

Keywords: Education management, Education policies, Education system, Legislative power, Representatives.

Öz: Türk eğitim politikalarının oluşturulmasında milletvekillerinin geniş yetkileri olduğu bilinmektedir. Dünyada meydana gelen küreselleşme süreci ile beraber çağdaş düşünce sistemlerine ve teknolojik gelişmelere uygun uzun soluklu eğitim politikalarının belirlenebilmesi ve toplumun bu yöndeki ihtiyaçlarının karşılanabilmesi seçilmiş milletvekilleri için önem arz etmektedir. Bu durum tüm siyasi partilerin tüzüklerinde ve programlarında eğitim, öğretim ve yönetim politikalarına yer vermesine gerekçe olmuştur. $\mathrm{Bu}$ araştırmanın amacı; milletvekillerinin Türk eğitim politikalarına yönelik algılarını ortaya koymaktır. Bu amaç doğrultusunda uluslararası sınav sonuçlarının Türk eğitim politikalarına ne şekilde yansıdığg; Türkiye'de öğretmenlerin yetiştirilmesi ve istihdamı ile ilgili geliştirilen politikalar; yöneticilerin istihdam süreçleri, milli hedeflere ulaşma noktasında Türk eğitim müfredatının kültürel ve ahlaki değerleri yansıtması ile ilgili sorulara yanıtlar aranmıştır. Nitel araştırmalardaki fenomenoloji deseni ile gerçekleştirilen araştırmaya; maksimum çeşitleme örneklemesi ile 5 milletvekili katılmıştır. Verileri toplamada araştırmacının geliştirdiği yarı yapılandırılmış görüşme formu kullanılmıştır. Araştırmanın bulgularında uluslararası sınavlar ile ilgili olarak eğitim politikalarının iyileştirilmesi, koşullu kabul ve uluslararası sınavların önemine; öğretmen yetiştirme politikaları ile ilgili olarak niteliksel sorunlar, formasyon, ideolojik ve teorik yönelimlere; öğretmenlerin istihdamı ile ilgili olarak akademik başarının azalması, arz talep dengesinin gözetilmesi ve kültürel aidiyet hissetmemeye; yöneticilerin istihdam süreçleri ile ilgili olarak liyakatin önemi, lisansüstü eğitim gereksinimi ve sendikal olumsuzluklara; müfredatın değerlere yansıması ile ilgili olarak da müfredatın yetersizliği, uygulama eksiklikleri ve kültürel erozyona değinilmiştir.

Anahtar Kelimeler: Eğitim yönetimi, Eğitim politikaları, Eğitim sistemi, Yasama erki, Milletvekilleri 


\section{Giriş}

Küreselleşen dünyada bilimin önem kazanması, modern düşünce sistemlerinin ve teknolojinin her alanda kullanılması ile beraber eğitim politikaları hayatın bütününde önemini arttırmıştır. Aynı zamanda bu eğitim politikaları, sanayileşme ve kalkınmanın ulusal ve uluslararası arenada değer bulmasıyla birlikte geniş kitlelerin toplumsal yaşantıya daha fazla katkı sağlayacak şekilde aktifleşmesine ve tüm kesimlerin eğitildiği okulların açılmasına vesile olmuştur. Bell ve Stevenson (2006) eğitim politikalarının gelişmiş ülkelerde değişim ve inovasyon sürecinde olduğunu ve tüm hükümetlerin eğitim politikalarının birçok farklı yönünü incelediklerini dile getirmiş̧ir. Siyasi partilerin ve siyasetçilerin de bu süreçlerde eğitim ve eğitim politikalarına müdahil olduğu bilinmektedir. Özsoy (2012) siyasetçilerin "eğitimi, siyasi rekabetin stratejik bir savaş alanı" olarak gördüklerini ifade etmektedir. Dolayısıla kimin neyi ne kadar öğreneceği toplumsal güç ilişkilerince belirlenmektedir. $\mathrm{Bu}$ nedenle eğitim politikaları üzerine yapılan tartışmalar basit birer atışma değil, politik güçlerin ve referans paradigmaların çarpışmasıdır.

Türkiye'de günlük konuşmada politika yerine siyaset kelimesi de kullanılmaktadır. Örgütlerin ve sistemlerin planlı bir şekilde yürütülmesi adına politikalara ihtiyaç duyulmaktadır. Bu politikaların belli bir standartta ve belli bir planlama ile oluşturulması gerekir. Politikalar, örgüt kararlarını ve eylemlerini yönlendirmek adına çıkarılmış ilkeler bütünüdür. Bu ilkelerin örgüt sorunlarını ve bu sorunların çözümlerini kapsaması gerekir. Politikanın amacı ise örgütlerin işleyiş sürecinde bütünlük, kararlılık, süreklilik ve tutarlık sağlamaya çalışmaktır (Bursalıoğlu, 2011: 100). Modern politika ise siyasal yapıdaki olguları, bireyler ve gruplardaki davranış yapılarını inceleyip bunlar arasındaki bağlar ve bu bağların nedenleri ortaya çıkarmayı amaçlayan bir bilimdir (Kapani, 1988: 23-25). Çağımızda tüm eğitim çalışmaları bir kamu politikası olarak planlanıp uygulanmaktadır. $\mathrm{Bu}$ sadece Türkiye'ye özgü bir durum değildir. Genellikle bütün dünya devletlerinde eğitim devlet tarafından gerçekleştirilir. Devletler kendi vatandaşlarının niteliklerini arttırmak ve devletin üretim faaliyetlerinde ihtiyaç duyulan kalifiye elemanları yetiştirmek adına verdikleri eğitimleri ücretsiz şekilde planlamaya gayret ederler. Türkiye'de verilen 12 ylllık zorunlu eğitim ücretsiz bir şekilde gerçekleştirilmektedir. Bu uygulamanın temelinde devletin eğitim politikaları yatmaktadır. Eğitim politikası kavramı, politika-eğitim ilişkisini ve bütünlügünü açıklayan bir ifadedir. Başka bir deyiş ile eğitim politikası; bir ülkede eğitim etkinliklerinin kendisine hedefler/amaçlar, yol/yöntem ve ilkeler belirlemesidir. Hiç şüphesiz ortaya konulan bu hedeflerle yöntemin kalitesi ve uygulamaya başlanıp başlanmadığı, eğitim sisteminde başarıyı belirleyen etmenlerdendir (Yılmaz, 2004). Farklı bir tanım ile eğitim politikaları; toplumların ya da eğitim kurumlarının, istenilen yaygın ve örgün eğitimin hedeflerine ulaşması adına alacakları kararlar adına hukuki bir dayanak sağlayacak genel bir planlamadır (Demirtaş ve Güneş, 2002: 50). Eğitim politikaları, çocukları ve gençleri merkeze alarak şu temel dayanaklar üstünde yükselir: "Bilim, kültür ve felsefe." (Yapıc1, 2006).

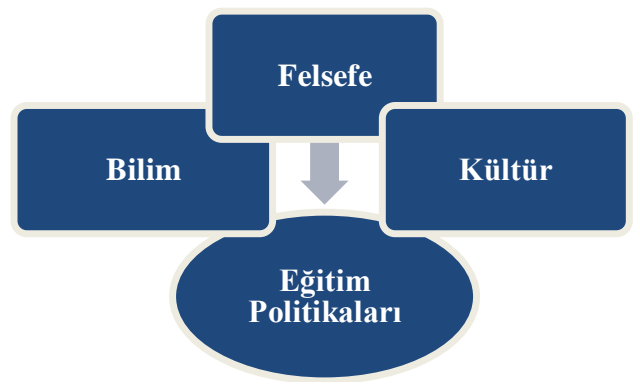

Şekil 1: Eğitim Politikası Dayanakları (Yapıc1, 2006)

Eğitim politikalarında öncelikli konular; eğitim kurumlarına alt yapı yatırımları, sınıf ve okulların fiziki durumları, kişilerin okul seçimleri, eğitim sisteminde özelleşme, öğretmenlerin yetiştirilmesi, öğretmenlerin istihdamının sağlanması, öğretmenlerin maaş durumları, öğretim 
yöntem ve teknikleri, eğitim programları, eğitim sistemindeki öncelik durumları, öğrencilere kazandırılması planlanan ana değerler vb. olarak sayılabilir (Aypay, 2015). Eğitim politikalarında gerçekleştirilen çalışmaların etkileri uzun y1llar sonra görülebilmektedir. Örneğin; Cumhuriyet kurulduktan sonra Atatürk dönemi eğitim politikalarının etkileri uzun yıllar sonra ortaya çıkmıştır. Bugün eğitim politikalarında gerçekleştirilen reform hareketleri de yıllar sonra meyvelerini verecektir. Eğitime yapılan yatırımların uzun soluklu olması ve ortalama olarak 20 ila 25 yıl sonrasında etkilerinin ortaya çıacağını düşündüğümüzde, eğitim politikalarını oluşturanların alacakları karar ve sorumluluklar sebebiyle bedel ödemeyecekleri bilinmektedir (Yapıc1, 2006).

Eğitim sisteminde oluşturulacak politikalar devletlerin yönetim şekillerine göre belirlenir. Devletler eğitim sistemlerinden beklentilerini karşılamak adına ülkedeki eğitim kurumlarını oluştururlar. Devletlerin eğitim kurumlarını oluşturmasının ve yönetimlerini sahiplenmesinin dört temel amacı bulunmaktadır. Bunlar;

1. Devletine bağlı uyumlu vatandaşlar yetiştirme,

2. Eğitim ile vatandaşları toplumun amaçlarına yönlendirme,

3. Ulusun eğitim ihtiyaçlarını karşılayıp, bireylere eğitim haklarını sunma,

4. Ülkenin ihtiyacı olan insan gücünü yetiştirme (Başaran, 1999: 91-92).

Çağımızda eğitim sistemleri kamunun bir politikası şeklinde planlanmakta ve uygulanmaktadır. Eğitim politikalarının oluşturulması ülkelerdeki siyasi sisteme göre; merkezi hükümet, yerel hükümet, yerel yönetim sistemleri veyahut birlik içerisinde yürütülmektedir. Türkiye'de eğitim politikaları zinciri TBMM ve buna bağlı olarak hükümetler tarafindan belirlenir ve uygulamaya konulur (Şişman, 2012: 107-114). Türkiye'de eğitim politikası oluşturulmasında Yükseköğretim Kurulu (YÖK), Millî Eğitim Bakanlığı (MEB), Devlet Planlama Teşkilatı (DPT) gibi kurumların yanında, siyasi partilerin de önemli görevleri bulunmaktadır (Adem, 1997: 52). Her siyasi partinin iktidara geldiği dönemde kendi eğitim politikalarını, hükümet politikaları ve devlet politikaları ile harmanlayarak eğitim sistemine yansıttıkları görülmektedir.

Avrupa Birliği'ne üyelik sürecinde olan Türkiye'de eğitim politikaları oluşturulurken Avrupa Birliği'nin eğitim politikalarının etkisi altında kalınmaktadır. Dolayısıyla Türk eğitim sistemi adına benimsenen eğitim politikaları, vatandaşlarımıza ulusal değerlerin yanında Avrupa Birliği’nin değerlerinin de aktarılmasına yol gösterecek şekilde planlanmaktadır. Avrupa'nın değerlerini yansıtan politika zincirlerinin oluşturulması, Avrupa Birliği üye ülkelerinin eğitim politikalarının incelenerek ulusal düzeydeki eğitim politikalarıyla bütünleştirilmesine bağlıdır (Terzi, 2005). Avrupa Birliği eğitim politikalarının temel hedefi, üye olan ülkelerin vatandaşları arasında oluşturulacak karşılıklı empati duygusunu özendirmek, üye olan ülkelerin vatandaşlarına Avrupa'lı olma bilincini kazandırmak, bu süreç içerisinde öğretmen ve öğrencileri eğitmek ve bütün AR-GE faaliyetlerine üye olan ülkelerin aktif bir şekilde katılımını sağlamaktır (Tuzcu, 2002). Türkiye, Avrupa Birliği uyum sürecinde Erasmus, Comenius, Socrates vb. değişim programlarından faydalanmaktadır. Bu değişim programları ile beraber öğrenciler, Avrupa Birliği Ülkeleri arasında değişim hareketliliği sağlamaktadır. Öğrenciler bu değişim programları ile Avrupa kültürünü, Avrupa vatandaşlığını ve Batı medeniyetlerininin özelliklerini tanımaktadırlar. Avrupa Birliği uyum süreci kapsamında eğitim politikalarında meydana getirilen değişimler ve güncellemeler, Türkiye'nin hem evrensel değerleri yakalaması hem de küresel kalkınmaya ayak uydurabilmesi bakımından önem arz etmektedir. Bu sebeple uluslararası eğitim politikalarını yasalaştıran milletvekillerinin görüşlerinin ne yönde olduğu değerlendirilmelidir.

Türkiye'de öğretmen yetiştirme politikaları eğitim sistemimizin en önemli konularından birisi olmasına rağmen sürekli değişime maruz kalmaktadır. Bu değişimin bazen olumlu bazen ise olumsuz yönleri bulunmaktadır. Eğitim fakültelerindeki öğretmen yetiştirme uygulamalarına baktığımızda değişimler ile beraber öğretmenlik mesleğinin niceliği artarken niteliği ise azalmaktadır. Öğretmenlik mesleğindeki niteliğin giderek azalmasının temel nedenleri arasında; öğretmen yetiştirme politikalarında gerçekleştirilen değişikliklerin kapsamlı araştırmalar ve 
planlamalar yapılmadan, politik olarak gerçekleştirilmesi yatmaktadır. Bunula beraber Türkiye'de, öğretmen yetiştirme sistemleri üzerine model arayışında içinde bulunduğumuz toplumun kültürel, sosyal, coğrafi ve ekonomik yapısına uyan bir model ortaya konulmadıkça bu sorunlar zamanla çoğalacaktır. Pedagojik formasyon ve tezsiz yüksek lisans eğitimi gibi geçici tedbirler ile bu soruna bir çözüm bulunamayacağı bilinmektedir (Azar, 2011). Özellikle bu sorunların giderilmesi için TBMM'ye öneri sunacak olan komisyonlar bulunmaktadır. $\mathrm{Bu}$ komisyonların üyeleri de milletvekillerinden oluşmaktadır.

Beş yıllık kalkınma planları incelendiğinde Türkiye'de öğretmenlerin istihdamının sağlanması noktasında tedbirler alınmaya gayret edilmiştir (DPT, 2009). Nitekim Türkiye'de öğretmenlerin istihdam problemleri hala çözülememiştir. Öğretmen yetiştiren fakültelerin dişındaki fakülteleri bitirip iş bulamayan mezunların ücretli olarak formasyon eğitimleri alıp öğretmen olabilmeleri öğretmen yetiştirme ve eğitim sisteminin kalitesini düşürmektedir. Bu durum öğrencilerin akademik başarılarını olumsuz yönde etkilemektedir. Aynı zamanda eğitim fakültelerinden mezun olan öğretmen adaylarının istihdamını da zora sokmaktadır. Eğitim fakültelerini kazanamayıp daha düşük puanlar ile başka bölümleri kazanabilen; sonrasında aldığı pedagojik formasyon eğitimi ile KPSS'de eğitim fakültesi mezunundan daha fazla puan alarak atanan "formasyonlu alan dışı mezunlar" eğitim fakültesi mezunu öğretmen adaylarının istihdamını güçleştirmektedir.

Eğitim hizmetlerinin verildiği yapılar okullardır. Okullar dışındaki bütün eğitim yapılarının oluşum nedeni, okulların iş ve işleyişlerini daha verimli bir şekilde yerine getirmesini sağlamaktır. Eğitim sisteminin hedeflerini gerçekleştirmesi okulların iyi örgütlenmesi ve iyi idare edilmesine bağlıdır (Kaya, 2005). Eğitim yönetimi, eğitsel amaçların başarılmasına dönük tüm madde ve insan kaynaklarını en verimli ve etkili biçimde kullanılması olarak ifade edilebilir. Eğitim yönetimi, tarihsel gelişim sürecinde kamusal tarafı ağır basan bir yönetim tatbiki olarak gelişme göstermiştir (Özdemir, 2009: 283). Bu neticede, kamu yönetiminin bir alt basamak şeklinde eğitim yönetimi incelenmekte ve değerlendirilmektedir (Bursalığlu, 2011: 5). Eğitim yöneticisinin görevi, eğitim yönetiminin en önemli işlevlerinden olan eğitim programlarını geliştirmek; öğrenci işlerini, okulun kurumsal ve eğitimsel amaçlarını, öğretme ve öğrenme süreçlerine yoğunlaşarak genel hizmetlerini, iş gören hizmetlerini ve bütçe işlerini etkili bir biçimde gerçekleştirecek şekilde yönetmektir (Çelik 2003: 43-46). Yöneticiliğin bir meslek olarak kabul edilebilmesi için bunun bir eğitiminin olması gerekir. Bu amaçla yönetici yetiştirme programlarının geliştirilmesi ve liyakat sahibi öğretmenlerin yönetici olarak istihdam edilebilmesi adına hem bakanlık hem de üniversiteler zaman kaybetmeden ortak bir şekilde çalışmalıdırlar (Işık, 2003: 207).

Türkiye'de sürekli değişen siyasi yönetimler ve bu değişimler neticesinde her yeni iktidarın değiştirip güncellemeye çalıştı̆̆ eğitim politikaları sonucunda eğitimde bir türlü yerli ve milli bir müfredat geliştirilememiştir. Okullarımızın bilişsel yönde hedefleri ile beraber vatanseverlik, saygilı olma, dürüst olma ve adil olma gibi birçok duyuşsal hedefleri olduğunu dile getiren Akbaş (2008); okulların görevlerinden bir diğerinin de, okul müfredatlarında açıkça belirtilen veyahut belirtilmeyen değerlerimizi öğretme, öğrencilerimizi belirlenmiş kurallar ile disipline etme, ahlakî gelişimlerine katkı sağlama ve karakter eğitimleri vermek olduğunu dile getirmiştir. Özellikle Türkiye'nin eğitim sisteminde milli hedeflere ulaşma noktasında belirleyeceği politikalarda Türk eğitim müfredatının içeriği, kültürel ve ahlaki değerleri içermesi, öğrencileri disipline eden kurallar bütününü bünyesinde barındırması önem arz etmektedir.

Türkiye'de TBMM milletvekilleri tarafından yasalaştırılan eğitim politikalarının eksik yönlerinden birisi de bu politikalarda istikrarın sağlanamamasıdır. Örneğin; uluslararası sınav sonuçları ve $\mathrm{AB}$ uyum süreci, müfredattaki kültürel ve ahlaki değerlerin durumu, öğretmen yetiştirme ve istihdam süreci, yöneticilerin atanması ve liyakat bağlamında sürekli bir değişim söz konusudur. Bu değişikliklerin altında yatan paradigmalar nelerdir? Bunun anlaşılması zor ve süreç isteyen bir durumdur. Türk eğitim sisteminin büyük ve geniş bir yapıya sahip olması nedeniyle 
gerçekleştirilen değişiklik ciddi anlamda zaman ve emek ve maddiyat kaybına yol açmaktadır. O halde eğitimde yaşanan bu politika problemlerin giderilmesinde yasama yetkisine sahip olan milletvekillerinin algıları ne yöndedir? $\mathrm{Bu}$ algıların belirlenmesi ülke açısından önemlidir. Milletvekillerinin eğitim politikaları ile ilgili algılarını inceleyen araştırmaların literatürdeki azlığı sebebiyle bu araştırmanın amacı "Yasama yetkisini elinde bulunduran TBMM milletvekillerinin Türk eğitim politikalarının oluşturulması ve geliştirilmesine yönelik algılarının ortaya çıkarılması" olarak belirlenmiştir. Araştırmanın amacına uygun olarak şu sorulara cevap aranmıştır:

1. Türkiye'deki öğretmenlerin yetiştirilmesi süreci ve öğretmenlerin pedagojik yeterlilikleri ile ilgili geliştirilen politikalar nasıl değerlendirilmektedir?

2. Eğitim ile ilgili uluslararası alanda yapılan (PISA, TIMMS gibi) sınav sonuçlarının ülkemizin eğitim politikalarına yansıması ne şekilde gerçekleşmektedir?

3. Öğretmen istihdamının sağlanması noktasında sistemin geliştirilmesi için neler yapılabilir? Mevcut öğretmen atama istihdam politikası öğrencilerimizin akademik başarılarını ne ölçüde etkilemektedir?

4. Eğitim sistemindeki yönetici atamalarının gerçekleştirilmesi aşamasında ne tür düzenlemelere ihtiyaç vardır?

5. Milli hedeflere ulaşma noktasında Türk Eğitim Müfredatı ülkemizin kültürel ve ahlaki değerlerini ne düzeyde yansıtmaktadır?

\section{Yöntem}

\section{Araștırmanın Modeli}

Araştırmada TBMM milletvekillerinin Türk eğitim politikalarına yönelik algılarının ortaya çıkarılması amacına uygun olarak "nitel yöntem” kullanılmıştır. Günümüzde eğitimle alakalı daha detaylı bilgi edinme ve nicel araştırmalarda var olan sınırlılıkları azaltılmak adına daha fazla nitel çalışmalara yönelinmektedir (Levent, 2009). Merriam (2009) nitel araştırmaların amacının bireylerin algıladığı gerçeği nasıl benimsedikleri ve inşa ettikleri üzerine odaklanması olduğunu belirtmiştir. Creswell (2009: 4) nitel araştırmayı bireylerin ve grupların sosyal ya da beşeri bir problemi keşfetmek ya da anlamlandırmak adına kullandıkları bir araç olarak tanımlar. Bu sebeple araştırma nitel araştırma desenlerinden "fenomenoloji" desenine uygun bir şekilde tasarlanmıştır. Fenomenoloji deseni, araştırmacının belirli bir olguya yönelik algılarını, deneyimlerini ve tepkilerini ortaya koymayı amaçladığı nitel desendir (Fraenkel, Wallen \& Hyun, 2012).

\section{Çalıșma Grubu}

$\mathrm{Bu}$ araștırmada çalışma grubu; "olasılıklı olmayan örnekleme türlerinden maksimum çeşitlilik örneklemesi" ile oluşturulmuştur. Olasılıklı olmayan örnekleme türünde evrende bulunan tüm öğelerin eşit şekilde seçilme imkânının olmadığı durumlar söz konusu olabilir (Silverman, 2013). Maksimum çeşitlilik örneklemesinde bir olgunun açıklanmasında çeşitlilik arz eden tüm durumların incelenmesi amaçlanmaktadır (Patton, 2002). Bu doğrultuda TBMM'de görev yapan ve farklı siyasi partilere mensup olan 5 milletvekili ile yarı yapılandırılmış görüşmeler gerçekleştirilmiştir. Araştırmaya katılımda gönüllülük ilkesi göz önünde bulundurulmuştur. Araştırmaya katılan TBMM milletvekillerinin demografik özellikleri şu şekildedir:

Tablo 1: Milletvekillerinin Cinsiyet Dağılımları

\begin{tabular}{lc}
\hline Cinsiyet & Milletvekili Sayıları \\
\hline Kadın & 2 \\
\hline Erkek & 3 \\
\hline TOPLAM & $\mathbf{5}$ \\
\hline
\end{tabular}

Tablo 1'de gösterildiği üzere araştırmaya katılan 5 TBMM milletvekilinin 2'si kadın, 3'ü erkektir. 


\begin{tabular}{lc}
\hline Tablo 2: Milletvekillerinin Yaş Aralıkları \\
\hline Yaş Aralı̆̆ı & Milletvekili Sayıları \\
\hline $20-29$ & 1 \\
\hline $30-39$ & 2 \\
\hline $40-49$ & 1 \\
\hline 50 ve üzeri & 1 \\
\hline TOPLAM & $\mathbf{5}$ \\
\hline
\end{tabular}

Tablo 2'de gösterildiği üzere araştırmaya katılan 5 TBMM milletvekilinden biri 20-29 yaş; ikisi 30-39 yaş; biri 40-49 yaş; biri de 50 ve üzeri yaş aralığındadır.

Tablo 3: Milletvekillerinin Akademik Unvanları

\begin{tabular}{ll}
\hline \multicolumn{1}{c}{ Ünvan } & Milletvekili Sayıları \\
\hline Profesör & 1 \\
\hline Dr. Öğr. Üyesi & 2 \\
\hline Unvan Yok & 2 \\
\hline TOPLAM & $\mathbf{5}$ \\
\hline
\end{tabular}

Tablo 3'te gösterildiği üzere yasama erkini temsilen araştırmaya katılan 5 milletvekilinden 1 tanesi profesör, 1 tanesi doktor öğretim üyesi, 3 tanesinin ise akademik bir ünvanı bulunamamaktadır.

Tablo 4: Milletvekillerinin Meslekleri

\begin{tabular}{lc}
\hline Meslek & Milletvekili Sayıları \\
\hline Akademisyen & 2 \\
\hline Öğretmen & 2 \\
\hline Ekonomist & 1 \\
\hline TOPLAM & $\mathbf{5}$ \\
\hline
\end{tabular}

Tablo 4'te gösterildiği üzere araştırmaya katılan 5 TBMM milletvekilinden 2 tanesi akademisyen, 1 tanesi öğretmen, 1 tanesi ise ekonomisttir.

Tablo 5: Milletvekillerinin Mezuniyetleri

\begin{tabular}{lc}
\hline Mezuniyet & Milletvekili Sayıları \\
\hline Doktora & 3 \\
\hline Yüksek Lisans & 1 \\
\hline Lisans & 1 \\
\hline TOPLAM & $\mathbf{5}$ \\
\hline
\end{tabular}

Tablo 5'te gösterildiği üzere araştırmaya katılan 5 TBMM milletvekilinden 3 tanesi doktora, 1 tanesi yüksek lisans, 1 tanesi ise lisans mezunudur.

Tablo 6: Milletvekillerinin Siyasi Partileri

\begin{tabular}{lc}
\hline Siyasi Parti & Milletvekili Sayları \\
\hline AK Parti & 1 \\
\hline CHP & 1 \\
\hline IYİ Parti & 1 \\
\hline MHP & 1 \\
\hline HDP & 1 \\
\hline TOPLAM & $\mathbf{5}$ \\
\hline
\end{tabular}

Tablo 6'da gösterildiği üzere araştırmaya katılan 5 TBMM milletvekilinden 1 tanesi AK Parti, 1 tanesi CHP, 1 tanesi IYYI Parti, 1 tanesi MHP ve 1 tanesi de HDP'ye mensuptur. 


\section{Veri Toplama Araçları}

Creswell (2009: 78) nitel veri toplamayı; araştırmanın sınırlarını koymak, yapılandırılmamış veya yarı yapılandırılmış gözlem, görüşme, belge veya görsel materyaller yoluyla bilgi toplamak, ilaveten bilgilerin ses kaydı için protokol oluşturmak olarak sıralamıştır. Merriam (1998: 114) ise nitel çalışmalarda incelenen fenomenin anlaşılması için gerekli olan nitel verilerin toplanmasında "görüşme" yönteminin ana kaynak olduğunu belirtmiştir. Fenomoloji deseninde bireylerin kendi deneyimlerinin detaylı olarak incelenmesi için görüşme, temel veri toplama aracı olarak görülmektedir (Fraenkel, Wallen ve Hyun, 2012). Bu araştırmada veriler araştırmacının geliştirdiği "yarı yapılandırılmış görüşme formları" ile toplanmıştır. Görüşme yöntemlerinde veri toplamada en yaygın olanının keşfedilmek istenen konu ile ilgili bir dizi sorudan oluşan "yarı yapılandırılmış görüşmeler" olduğu vurgulanmaktadır. Bu araştırmada yarı yapılandırılmış görüş̧me türü kullanılmaktadır. Bu görüşme türünde sorular önceden hazırlanır fakat bireylere esneklik sağlamak adına yeniden düzenlenme ve tartışılmaya olanak verilir. Yarı yapılandırılmış görüşmelerde, araştırma yapılan bireylerin de araştırma üzerinde etkileri olabilir. (Ekiz, 2003: 62). Merriam (1998: 93) yarı yapılandırılmış görüşmeyi, bireyin tecrübelerinin özünü ortaya çıkaran soruların içinde bulunduğu veri formları olarak tanımlamaktadır. Görüşme formu oluşturulurken alan yazın incelenmiş ve eğitim yönetimi denetiminde uzman 4 kişiye ve ölçme değerlendirme alanında uzman 1 kişiye anlaşılabilirlik ve kapsam açısından değerlendirilmesi adına sunulmuştur. Alının dönütler doğrultusunda görüşme formu son halini almıştır.

\section{Verilerin Toplanması}

Araştırmanın verileri, araştırmaya katılan TBMM milletvekilleri ile gerçekleştirilen "yarı yapılandırllmış görüşmeler" yoluyla toplanmıştır. Görüşmeye katılacak milletvekillerine araştırmanın konusu ile ilgili önceden bilgi verilmiştir. Görüşme süreci, katılımcıların izinleri doğrultusunda ses kaydı alarak gerçekleştirilmiştir. Ses kaydı alınması istenmeyen durumlarda ise ayrıntılı notlar tutulmuştur. Görüşmelerin nerede yapılacağ kayıt altına alınmıştır. Tablo 7'de görüşme yapılan grup ile ilgili bilgiler verilmiştir. Görüşmeler 21.05.2018 ve 25.06.2018 tarihleri arasında çoğunluğu (3/5) Ankara ilinde Türkiye Büyük Millet Meclisinde gerçekleşmiş; bir kısmı ise (2/5) milletvekillerinin bulundukları illerde parti il binalarında gerçekleştirilmiştir. Görüşme süreleri açısından bakıldığında; görüşmeler ortalama 26 dakika ile 71 dakika aralığında gerçekleşmiştir. Ses kaydı yoluyla toplanan veriler yazılı döküm haline getirilmiştir.

Tablo 7: Çalışma Grubuna Ait Görüşme Bilgileri

\begin{tabular}{|c|c|c|c|c|c|}
\hline No & $\begin{array}{l}\text { Vekil } \\
\text { Kodu } \\
\end{array}$ & $\begin{array}{c}\text { Görüşme } \\
\text { Tarihi }\end{array}$ & $\begin{array}{c}\text { Görüşme } \\
\text { Saati }\end{array}$ & $\begin{array}{c}\text { Görüşme } \\
\text { Yeri }\end{array}$ & $\begin{array}{c}\text { Görüş̧me } \\
\text { Süresi } \\
\end{array}$ \\
\hline 1 & M1 & 28.05 .2018 & $11: 15$ & Türkiye Büyük Millet Meclisi & $1 \mathrm{sa} 11 \mathrm{dk} 11 \mathrm{sn}$ \\
\hline 2 & M2 & 21.05 .2018 & $16: 20$ & Türkiye Büyük Millet Meclisi & $26 \mathrm{dk} 01 \mathrm{sn}$ \\
\hline 3 & M3 & 23.05 .2018 & 13:05 & Türkiye Büyük Millet Meclisi & $55 \mathrm{dk} 54 \mathrm{sn}$ \\
\hline 4 & M4 & 25.06 .2018 & $10: 00$ & Parti İl Binası & $47 \mathrm{dk} 12 \mathrm{sn}$ \\
\hline 5 & M5 & 05.06 .2018 & 09:20 & Parti İl Binası & $32 \mathrm{dk} 24 \mathrm{sn}$ \\
\hline
\end{tabular}

\section{Verilerin Analizi}

Bu araştırmada veri analiz sürecinde "içerik analizi" yöntemi kullanılmıştır. İçerik analizi ile edinilen veriler kavramsallaştırılır, anlaşılacak bir biçimde düzenlenir ve temalar oluşturulur (Yıldırım ve Şimşek, 2013). İçerik analizi yönteminde amaç; görüşmeler ile toplanmış ve birbirine benzeyen verileri belli temalarda toplamak ve bu temaları düzenli bir biçimde aktarmaktır (Metin, 2014). Nitel veri analizlerinin bilgisayar programları ile yapılması verilerin yoğunluğu ve karmaşıklığı ile başa çıkma ve tüm verileri inceleyebilme imkânı sağlar (Gibbs, 2017: 415). Öncelikle 5 görüşme dokümanı yazı ile bilgisayar ortamına aktarılmıştır. Görüşmeler sonucunda 21 sayfa doküman elde edilmiştir. 5 görüşme dokümanı milletvekili kodları ile (M1, M2, M3, M4, M5) kaydedilmiştir. Daha sonra elde edilen dokümanlar MAXQDA 2018 yazılımı ile 
düzenlenmiştir. Verilerin analizi için dokümanlar tekrar tekrar okunarak ve her bir detaya dikkat edilerek araştırma soruları kapsamında incelenmiştir. Elde edilen veriler bulgular bölümünde araştırma sorularına göre sistematik bir şekilde verilmiş ve doğrudan alıntılarla desteklenmiştir.

\section{Geçerlik ve Güvenirlik}

Genel olarak geçerlik; araştırma sonuçlarının doğruluğu ile ilişkili iken güvenirlik; çalışmaya ait bulguların tekrar edilebilirliği ile ilgilidir (Yıldırım ve Şimşek, 2013). Nitel çalışmaların geçerlik ve güvenirlik analizleri nicel araştırmalardan farklıdır. Guba (1981) nitel araştırmalarda geçerlik ve güvenirliği bazı kavramlarla açıklamaktadır. Bu kavramlar; inandırıcılık, aktarılabilirlik, tutarlık ve doğrulanabilirliktir.

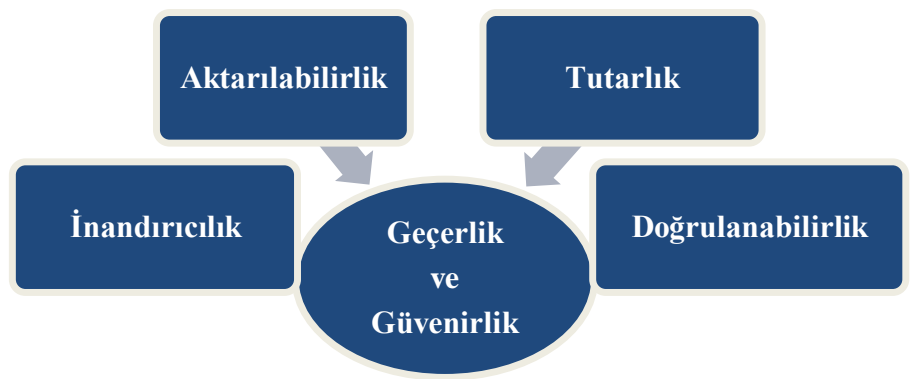

Şekil 2: Guba'nın Geçerlik ve Güvenirlik Kavramları

Inandırıcılık araştırmanın her aşamasında nesnellik sağlanmasıyla ilgilidir. Nitel araştırmaların doğası gereği genellenebilirliği yoktur fakat nitel aktarılabilirlik kavramıyla araştırma sonuçlarının benzer ortamlara aktarılması ifade edilmektedir. Tutarlık, olguların değişebilirliğini araştırmaya tutarlı bir şekilde yansıtabilmektir. Doğrulanabilirlik ise toplanan verilerin teyit edilmesi ve mantıklı şekilde açıklanarak sunulmasıdır. Bu kavramların yanında Cresswell ve Plano Clark (2011) nitel araştırmalarda iç geçerlilik için uzman görüşü alma, detaylı betimleme ve yeterli kanıt sunma stratejilerini önermektedir. Bu araştırmada; veri toplama araçlarının geliştirilmesinden, veri analiz sonuçlarının yazılmasına kadar beş eğitim bilimleri uzmanın görüşüne başvurulmuştur. Çalışmadan elde edilen verileri toplama sürecinin detaylı bir şekilde raporlanması ve araştırmacının sonuca nasıl ulaştı̆̆ının açıklanması nitel araştırmalarda geçerlik için önemli kriterler arasındadır (Creswell, 2009). Bu bağlamda çalışmada elde edilen verilere ait frekans bilgileri, katılımcıların demografik bilgileri ve sayısı, doğrudan yapılan alıntılar, katılmcı kodları ve kavramsal kategoriler detaylı bir şekilde sunulmaya çalışılmıştır.

\section{Bulgular}

Araştırmada verilerin analizi sonucu elde edilen bulgular "Türk Eğitim Politikaları" ana teması altında kodlardan oluşturulan beş alt temada sunulmuştur. Verilerin analizleri sonucunda elde edilen bulgular; tema, alt tema ve kodlar şeklinde açıklanmıştır. Aşağıda "Türk Eğitim Politikaları" temasının alt temaları ve kod frekansları tablo 8'de gösterilmiştir. Bu alt temalar öğretmen yetiştirme politikaları, uluslararası sınavlar, öğretmenlerin istihdam politikaları, yöneticilerin istihdam politikaları ve müfredatın ulusal değerlere yansımasıdır.

Tablo 8: Türk Eğitim Politikaları Alt Temaları ve Kod Frekansları

\begin{tabular}{lll}
\hline \multicolumn{1}{c}{ Alt Temalar } & Kod Frekansları \\
\hline & \multicolumn{1}{c}{ Öğretmen Yetiştirme Politikaları } & $\mathbf{4}$ \\
\hline & Uluslararası Sınavlar & $\mathbf{3}$ \\
\hline & Öğretmenlerin İstihdam Politikaları & $\mathbf{3}$ \\
\hline & Yöneticilerin İstihdam Politikaları & $\mathbf{3}$ \\
\hline
\end{tabular}

Turkish Studies - Education, 15(3) 
Öğretmen yetiştirme politikaları alt teması niteliksel sorunlar, formasyon, ideolojik ve teorik yönelimler; Uluslararası sınavlar alt teması eğitim politikalarının iyileştirilmesi, koşullu kabul ve uluslararası sınavların önemi; Ögretmenlerin istihdam politikaları alt teması akademik başarının azalması, arz-talep dengesinin gözetilmesi ve kültürel aidiyet hissetmeme; Yöneticilerin istihdam süreçleri alt teması liyakatin önemi, lisansüstü eğitim gereksinimi ve sendikal olumsuzluklar, Müfredatın değerlere yansıması alt teması da müfredatın yetersizliği, uygulama eksiklikleri ve kültürel erozyonu kapsamaktadır.

\section{Öğretmen Yetiștirme Politikaları}

Araştırmada öğretmen yetiştirme politikaları alt temasının niteliksel sorunlar, formasyon, ideolojik ve teorik yönelimler kodları ilişkilendirildiği görülmektedir. Şekil 3'te kodlar şu şekilde gösterilmiştir:

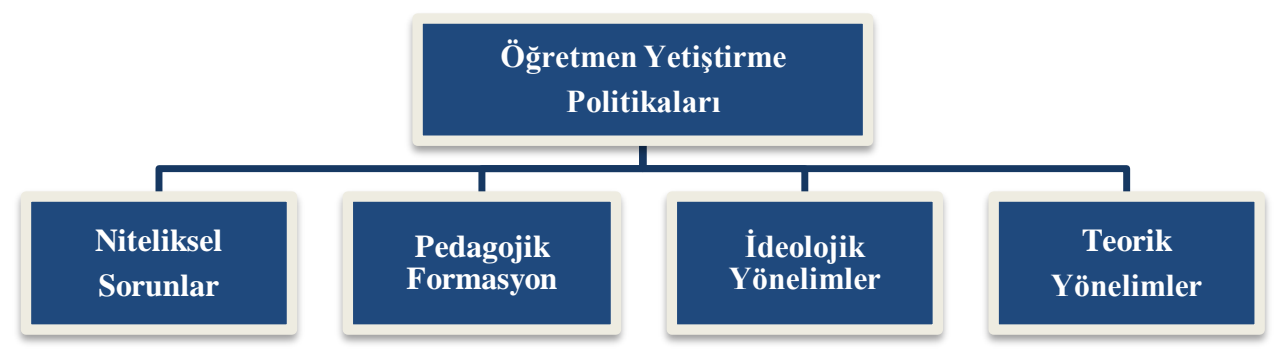

Şekil 3: Öğretmen Yetiştirme Politikaları Kodları

\section{Niteliksel Sorunlar}

Görüşmeye katılım sağlayan milletvekillerinin öğretmen yetiştirme politikaları alt temasında üzerinde önemle durdukları ve sıklıkla dile getirdikleri ilk konu niteliksel sorunlardır. Niteliksel sorunlar ile ilgili olarak açıklamalardan bazıları şu şekildedir:

Eğitim fakültelerimizin bazı eksiklikleri olduğunu fakat bu eksikliklerin geliştirilmeye açı olduğunu belirtmek isterim. Bu anlamda öğretmenlerin pedagojik yeterliklerinin geliştirilmesi için açılan formasyon ve hizmetiçi eğitim kurslar telafi niteliği taşımaktadır. Diğer yandan klinik uygulamaların daha ön planda olduğu, öğrenciye dokunarak kendini gelişstirebilen hizmetiçi eğitim programlarına ihtiyacımızın olduğunu düşünmekteyim. (M1)

Öğretmenliğin özüne bakttğımızda bu mesleğin bir sanat olduğunu düşünüyorum... Ögretmenlik aslında sadece eğitim fakültelerinden bilgi almak değil, eğitim hayatı boyunca ögretmen adaylarının öğrendiklerini en iyi ssekilde öğrencilere aktarmak olarak adlandirllmaktadır. Öğretmen yetiştirme sürecinde önemli olan nitelikli personeller yetiştirmek olmalıdır. Öğretmenlerin ders anlattıktan sonra sinıfa şöyle bir baktı̆̆ında; kimin dersi anlayıp kimin anlamadı̆̆ın bilmesi gerekmektedir. Konuları anlamayanlar için düzeltmeler yapması gerekmektedir. Iște nitelikli öğretmen bu şekilde olur. Kimin boş yere kafa salladığını, kimin gerçekten öğrendiğini iyi analiz etmelidir. Isste bunlar pedagojik yeterliliklerin önceliklerindendir. Öğretmen dediğin anlayanlara odaklanan değil anlamayanlar için çaba sarf eden birey olmalıdır. (M2)

Ĕgitim fakültelerinde uygulanan müfredatlarının niteliğinin azaldı̆ğ ve artık güncellenmesi gerektiği yönünde siklkkla görüşümü ifade ederim. Ülkemizde uygulanan ve eğitim fakültelerinde ögretilen ögrenme metotları üzgünüm ki ilkelleşti. (M3)

Türkiye'deki eğitim fakültelerinden ya da pedagojik formasyon veren kurumlardan nitelikli öğretmenler çıkabilir. Fakat siz nitelikli bir eğitim sisteminin temellerini oluşturamazsanız doğal olarak nitelikli ögretmenler mezun edemezsiniz. Maalesef ki zihniyet, nitelikli ögretmen yetiştirme üzerine kurulmamıștr. (M5) 
Açıklamalar neticesinde bir kısım milletvekilinin görüşleri incelendiğinde öğretmen yetiştirme politikaları alt temasında niteliksel sorunlar ile ilgili olarak; eğitim fakültelerinde nitelik eksikliklerinin bulunduğuna ama bu eksikliklerin giderilebilir düzeyde olduğuna, mevcut öğretmenlerin de nitelik güncellemelerinin hizmet içi eğitimler ile giderilebileceğine, bu eğitimlerde uygulamalı çalışmaların ağırlıklı olması gerektiğine değinilmiştir. Öğretmenliğin bir sanat olduğunu dile getiren bazı milletvekilleri; bu mesleğin sadece salt bilgiler ile donanmak değil, eğitim hayatları boyunca edinecekleri bilgileri öğrencilere en iyi şekilde aktarmak olduğuna, sınıfındaki öğrencilerden hangisinin anladığını hangisinin anlamadığının farkına varmak ve anlamayanlar için çaba sarf etmek olduğuna değinilmiştir. Bununla beraber eğitim fakültelerindeki müfredatın niteliğini kaybettiğine ve öğrenme metotlarının ilkelleştiğine değinen bazı milletvekilleri; Türkiye'deki eğitim fakültelerinden kaliteli ve nitelikli öğretmenler çıkabileceğine ama bunun öncesinde nitelikli eğitim politikalarına ihtiyaç duyulduğuna değinmişlerdir.

\section{Pedagojik Formasyon}

Görüşmeye katılım sağlayan milletvekillerinin öğretmen yetiştirme politikaları alt temasında üzerinde önemle durdukları bir diğer konu pedagoijik formasyondur. Pedagojik formasyon ile ilgili olarak açıklamalardan bazıları şu şekildedir:

Öğretmenlik mesleği ister pedagojik yönden olsun, ister ahlaki yönden olsun, ister
yetiştirilme süreci olsun bana göre Allah tarafindan özel insanlara verilmiş bir nimettir.
Eğitim fakültesi mezunu olup bu niteliklere sahip olan ögretmen adaylarının
ögretmenlik mesleğini rahatlkla yapabileceğini düşünüyorum ama bununla beraber
ögretmenlik kabiliyetine sahip fen edebiyat fakültesi veyahut ilahiyat fakültesi mezunu
olup formasyon almış gençlerimizin de bu kabiliyetleri var ise öğretmen
olabileceklerine inaniyorum. Bu yüzden ögretmen yetiştirme sürecinde geliştirilecek
politikalarda fen edebiyat ve ilahiyat fakültelerine de yer verilmesi gerektiğini
düşünüyorum. (M2)

Türkiye'de ögretmenlerin pedagojik yeterliklerini yetersiz görüyorum. Bana göre bir yll süren formasyon eğitimleri ile pedagojik eğitim veremezsiniz. Özellikle ögrretmenlik, ögrencilerin kendilerine rol model seçtikleri bireylerin mesleğidir. Bu sebep ile formasyon ĕ̆itimlerinin uzatılması eğer uzatılmıyorsa da sadece eğitim fakültelerinden mezun olan adayların ögretmenlikte istihdam edilmesi gerekmektedir. (M3)

Hızlandırılmış bir şekilde formasyon alarak öğretmen olanlar maalesef ki eğitimde kaliteyi düşürmektedir. Öğretmenlik mesleği hassas bir meslektir. Bu sebep ile ögretmen olacakların ĕgitim fakültelerinden nitelikli bir pedagojik formasyon eğitimi alması gerekmektedir. Fen edebiyat fakülteleri ve diğer bölümlerin formasyon almasının önüne geçilmesi bir politika gereksinimidir. (M5)

Açıklamalar neticesinde bir kısım milletvekilinin görüşleri incelendiğginde öğretmen yetiştirme politikaları alt temasında pedagojik formasyon ile ilgili olarak; öğretmenlerin pedagojik yeterliliklerinin aldıkları eğitim kaynaklı olarak yetersiz kaldığına, eğitim fakülteleri haricindeki fakültelerde k1sa sürede verilen formasyon eğitimleri ile nitelikli öğretmen istihdamı sağlanamayacağına, bu şekilde öğretmen yetiştirilmesine devam edilmemesi gerektiğine değinilmiştir. Öğretmenlik mesleğinin Allah tarafından ayrıcalıklı bireylere tanınan bir lütuf olduğuna değinen bazı milletvekilleri; eğer bu ayrıcalığa sahip ve gerekli olan eğitimcilik yeteneğini kazanmış ise formasyon alan adayların da öğretmenlik yapabileceğine, öğretmen yetiştirme sürecindeki eğitim politikalarında fen edebiyat ve ilahiyat fakültelerinin de gündeme dâhil edilmesi gerektiğine değinmişlerdir. Öğretmenlik mesleğinin hassas bir meslek olduğuna; eğer niteliksiz, kısa sürede ve uygulamalı eğitimlerden uzak formasyon eğitimleri verilecekse de bu durumun önüne geçilmesinin bir eğitim politikası gereksinimi olduğuna da önemle vurgu yapılmıştır. 


\section{İdeolojik Yönelimler}

Görüşmeye katılım sağlayan milletvekillerinin öğretmen yetiştirme politikaları alt temasında bahsettikleri diğer bir konu da ideolojik yönelimlerdir. İdeolojik yönelimler ile ilgili olarak açıklamalardan bazıları şu şekildedir:

Öğretmenlerin devlet ülkülerini çocuklara iyi aktaran bireylerden seçilmesi gerektiği unutulmamalıdır. Eğitim fakültelerinde ders verecek akademisyenlerin yeterliliklerinin gözden geçirilmesi ve bu akademisyenlerin siyasibir ideolojiye sahip olmamast gerekmektedir. (M2)

Eğitim sektöründe kendime göre bir toplum yaratacağım diyorsanız, ideolojik olarak sadece kendime bir oy potansiyeli yaratmak istiyorum diyorsaniz, eğitimle yetişecek bireyler sadece beni iktidarda tutsun diyorsanı toplumun bütün damarlarlyla oynamış olursunuz. Örneğin Hazreti Ali: "Bana bir harf ögretenin 40 yll kölesi olurum" diyor. Fatih Sultan Mehmet Istanbul'u fethettiğinde ziyarete gelmek isteyenlere şunu diyor: "Benim hocama gidin!" Eğitmenlik gerçekten çok kutsal bir görevdir. Tabiki eğitim verecek insanın eğitimi de çok önemlidir. Öğretmeni kimin için yetiştirdiğimiz çok önemlidir. Niçin yetiştirdiğimiz çok önemlidir... Öğretmenlerin pedagojik yeterlikleri topluma göre şekil göstermelidir. Hükümetlerin eğitim politikalarına göre değil. Öğrenciler yetiștirilirken özellikle ögretmenler, topluma șekil vermelidir. Fakat bu șekil verme birilerinin politik ideolojisi uğruna gerçekleştirilmemelidir... Hükümetler kendilerine itaat edecek ögretmen yetişstirmek istiyorlar. Bu yüzden bilimsel alanda ilerleme ve teknolojiye ayak uydurmakta güçlük çekiyoruz. (M4)

Açılamalar neticesinde bir kısım milletvekilinin görüşleri incelendiğinde öğretmen yetiştirme politikaları alt temasında ideolojik yönelimler ile ilgili olarak; öğretmenlerin tek bir ideolojik görüş ile yetiştirilmesinin olumsuzluklarına, öğretmenlerin tek bir siyasi düşünceye sahip adaylar arasından seçilmesinin sıkıntılarına değinilmiştir. Aynı zamanda öğretmenlerin devlet ülküsüne sahip bireylerden seçilmesinin öneminden ve öğretmenlere verilen değerin arttırılmasından da bahsedilmiştir.

\section{Teorik Yönelimler}

Görüşmeye katılım sağlayan milletvekillerinin öğretmen yetiştirme politikaları alt temasında bahsettikleri bir diğer konu da teorik yönelimlerdir. Teorik yönelimler ile ilgili olarak açıklamalardan bazıları şu şekildedir:

....sadece teorik bilgilerle donatılmış ögretmenlerin okullara gönderilmesi, sinıflarda uygulamall çalışmaların geri planda kalmasina sebebiyet verecektir. Bu durum ögrencilerin akademik başarllarının olumsuz yönde etkilenmesinin ana nedenidir. (M1)

Öğretmen yetiştirme müfredatlarını incelediğimizde maalesef ezberci bir eğitim sisteminin hedef güdüldü̈g̈̈nü görmekteyim. 16 ylldır yap-boz şeklinde her bakan değişiminde yeni bir müfredat uygulanmaya çallşıllmış ve sonuç olarak başarısızlıklarla karşılaşılmıştır. Öğrencilerimizin okullarda uygulamadan uzak, pratikten uzak ve sadece teorik bilgilerle donatılması çok sikıntılı bir süreçtir. (M2)

OECD ülkelerinde bir insanı yetiştirmek için kiși başına 10.500 dolara yakın masraf yapllyyor. Türkiye'de ise bu ortalama 4.000 dolar civarindadir. Ortaokul ve liseye geldiğinde ise 3.000 dolar civarındadir. Yani 3'te 1 oranındadir. Simdi siz teknoloji boyutunda eğitime pay ayırmazsanız, bu politikalarda nasıl düzenlemeler yapacaksınız? Sadece ezbere dayalı teorik bilgilere sahip teknik eğitimciler hazırlarsınız. (M4)

Öğretmenler hızl bir şekilde sadece teorik bilgiler ile fakültelerden mezun oluyorlar. Bunun ivedi bir şekilde düzeltilmesi gerekmektedir... Öğretmen adaylarının sadece nitelikli bir şekilde mezun olurlarsa atanacaklarını bilmesi gerekmektedir. Böylece kendilerini alacakları eğitimlere motive edeceklerdir. (M5)

Açıklamalar neticesinde bır kısım milletvekilinin görüşleri incelendiğinde öğretmen yetiştirme politikaları alt temasında teorik yönelimler ile ilgili olarak; teorik bilgilerle mezun edilen öğretmenlerin sınıflarında uygulamalı ve öğrenci merkezli eğitimleri gerçekleştiremediğine; 
sonuç olarak öğrencilerin akademik başarılarının olumsuz yönde etkilendiğine, öğretmen yetiştirme müfredatlarında ezberci bir eğitim sisteminin kullanıldı̆̆ına ve sürekli değişen bakan ve bakanlık yapıları ile beraber öğretmen yetiştirme politikalarının da sekteye uğradığına, Türkiye'deki kişi başına düşen eğitim harcamalarının azlığından dolayı eğitim fakültelerinde uygulama ve teknolojiden uzak, sadece teorik bilgilerle donatılmış öğretmenlerin yetiştirildiğine ve öğretmen adaylarının sadece nitelikli eğitimler aldıktan sonra atamalarının yapılabileceğini bilmeleri gerektiğine değinilmiştir.

\section{Uluslararası Sinavlar}

Araştırmada uluslararası sınavlar alt temasının eğitim politikalarının iyileştirilmesi, koşullu kabul ve uluslararası sınavların önemi kodları ilişkilendirildiği görülmektedir. Şekil 4 ’te kodlar şu şekilde gösterilmektedir:

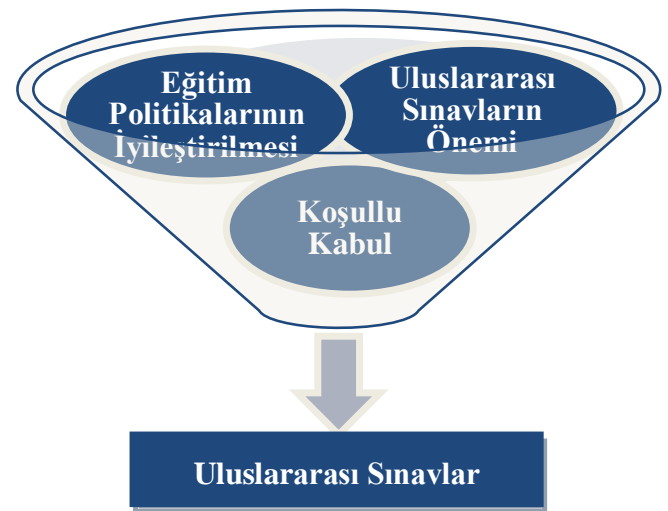

Şekil 4: Uluslararası Sınavların Kodları

\section{Eğitim Politikalarının İyileştirilmesi}

Görüşmeye katılım sağlayan milletvekillerinin uluslararası politikalar alt temasında üzerinde önemle durdukları ve sıklıkla dile getirdikleri ilk konu eğitim politikalarının iyileştirilmesidir. Eğitim politikalarının iyileştirilmesi ile ilgili olarak açıklamalardan bazıları şu şekildedir:

Uluslararası alanda gerçekleştirilen çalışmaların ülkemiz eğitim politikalarına yansıtılmasını iki açıdan değerlendirmek isterim. Birincisi ülkemiz ĕgitim sistemine olumlu yansımaları; ikincisi sadece sadece ders çıkarlması gereken olumsuz yansımalar. Ĕ̈itimde diğer ülkeler bakımından küresel yapıda neler olup bittiğinin incelenmesi, analizlerin yapılmast ve bu durumların değerlendirilmesi adına uluslararası çalışmaların üzerinde durulması kesinlikle bir ihtiyaçtır. Fakat daha önceki dönemlerde olduğu gibi bu sınav sonuçlarının ve yabanct sistemlerin direk olarak eğitim politikalarımıza yansıtılmasını doğru bulmuyorum. (M1)

Ĕ̆itim sistemimizin bu sınavlar ile karşılaștırıldığında uluslararası başarısı, evrensel bilgi düzeyimize olumlu katkı sağlayacaktır. Fakat ülke genelinde ve uluslararası düzeyde ülkemizin eğitim politikalart ve eğitim uygulamalar daha üst seviyede etkileşim gösterirse bireysel başarıların daha da artacağını ümit etmekteyim. (M3)

Ĕgitim ve bilgi kapasitesinin artırılması artık bölgesel düzeyde değil evrensel düzeyde gerçekleştirilmektedir. Evrensel bilginin test edilmesi ancak bu tür sinavlar ile sağlanabilir. Rekabetçi bir eğitim politikası ve öğretim sistemi ülkemizin eğitim sisteminin uluslararası seviyeye ulaştırarak dünya ile klyaslanabilir bir seviyeye ulaştırabilir. (M4) 
Kendi ĕgitim sistemimizin alt yapısını düzene sokmadan, kendi sorunlarımızı çözmeden ve sorunlarımıza çözümler üretmeden uluslararası alanda gerçekleştirilen bu tür sınavlara girmek, liseyi bitirmiş bir vatandaşın üniversite mezunu vatandaşlar ile yarışması ile denk olacaktır. Bunun nasıl sonuçlar doğuracă̆ını hepimiz tahmin etmekteyiz ve görüyoruz. (M5)

Açıklamalar neticesinde bır kısım milletvekilinin görüşleri incelendiğinde uluslararası sınavlar alt temasında eğitim politikalarının iyileştirilmesi ile ilgili olarak; bu sınav sonuçlarının eğitim politikalarımıza olumlu veya olumsuz yansımalarının olabileceğine fakat tüm bu yansımalardan ders çıkarılarak eğitim politikalarının güncellenip geliştirilebileceğine değinilmiştir. Türkiye'nin küreselleşen dünyada diğer ülkelerin eğitim sistemleri ile mukayese yapabilmesi adına bu sınav sonuçların iyi analiz edilerek Türk eğitim politikalarına yön vermesi gereklidir. Bu sınavlarda alınacak başarılar eğitim sistemimize olumlu katkılar verecektir. Bununla beraber eğitimde kapasite arttırma çalışmalarının artık evrensel düzeyde gerçekleştiğini dile getiren bazı milletvekilleri; bu kapasiteyi oluşturacak politikaların iyileştirilmesi için sınav sonuçlarının değerlendirilmesinin şart olduğuna değinmişlerdir. Aynı zamanda kendi eğitim politikalarımızı iyileştirmeden bu tür sınavlara girmenin yaratacağı olumsuz durumlara da dikkat çekilmiştir.

\section{Uluslararası Sınavların Önemi}

Görüşmeye katılım sağlayan milletvekillerinin uluslararası politikalar alt temasında üzerinde önemle durdukları bir diğer konu da uluslararası sınavların önemidir. Uluslararası sınavların önemi ile ilgili olarak açıklamalardan bazıları şu şekildedir:

Bu sınavlarda elde ettiğimiz sonuçlar istendik yönde olmadığ için çeşitli değişiklikler ve güncellemeler yoluyla başarının arttırılması hedeflenmektedir. Örneğin; 2017 yılında güncellenen ögretim programlarının temel güncelleme gerekçelerinden biri olarak bu sinavlardan elde edilen başarısıllklar gösterilmektedir. Bununla birlikte ögretmen yeterliliklerinde, öğrenci başarılarının ABIDE gibi sınavlarla ölçülmeye çalışılması gibi uygulamalara da ön ayak olduğu söylenebilir. (M1)

Bu sınavların ülkemizde yapılması, Türk eğitim politikalarına olumlu yansımaların sağlanması ve uluslararası alanda başarının desteklenmesi açısından oldukça önemlidir. (M2)

Finansmanının uluslararası kurumlar tarafindan să̆lanması, bu tip sınavların değerini daha da arttırmaktadır. Öğrencilerin, ögretmenlerin ve ĕgitim kurumlarının kendilerini görmeleri açısından diğer ulusların ĕgitim politikaları ile kıyaslar yapılması önemlidir. Biz diyoruz ki, ögrenciler bir toplumun geleceğidir. Bu yüzden bu sinavların eğitim politikalarımız ile karşılaştırılması bizim çok yararımıza olacaktır. Yani siz eğitimciler gelecek toplumu yetiştiriyorsunuz. Bu yüzden farkl yetiştirme sistemleriyle mukayeseler yapmanı sizin menfaatinize olacaktır. Unutmayalım ki küreselleşme kavramı ile beraber uluslar bu tip sınavların sonuçlarını kullanarak eğitim politikalarını ve sistemlerini güncelliyorlar. (M4)

Ĕ̈itimcilerin pozisyonunu anlama, ĕgitim kurumlarının öğrenciye verdiği beceriler, maharetler ve değerleri ölçme anlamında bu tür karşılaştırmalar önemlidir. (M4)

Ülkemizin eğitim sistemi maalesef ki 137 ülke arasında 99. sirada kendisine yer bulmuştur. Demek ki uluslararasi alanda yapılan PISA ve TIMMS gibi sinavlardan yeterince ders çıkarılmamaktadır. Sadece bu sınavları temel alarak değil, uluslararası alanda yapılan araştırmalara da bakıldı̆̆ında ülkemiz maalesef Mozambik, Tanzanya, Etiyopya gibi üçüncü dünya ülkeleriyle aynı yüzdelik dilimde yer almıştır. Beğenmediğimiz Pakistan, Malezya ve Katar gibi ülkelerin gerisinde kalmış durumdayı. OECD, TIMMS vb. sinav raporlarl incelendiğinde sinava giren ülkeler arasında maalesef ki hep son siralarda kendimize yer bulmaktayı. Isşte bu sebeple uluslararası alanda yapılacak sınavların göstergeleri bizim için önemli sayılmall ve kıyas ölçüsü olmalıdır. (M5) 
Açıklamalar neticesinde bır kısım milletvekilinin görüşleri incelendiğinde uluslararası sınavlar alt temasında bu sınavların önemi ile ilgili olarak; sınav sonuçlarında istenilen başarı elde edilmediğinden dolayı eğitim politikalarımızda güncellemeler yapıldığına ve kendi iç değerlendirme sınavımızı oluşturduğumuza değinilmektedir. Aynı zamanda bu sınavların finansmanının uluslararası kurumlar tarafından sağlanmasının sınavların değerini arttırdığına değinen bazı milletvekilleri; eğitim paydaşlarının kendilerini diğer toplumların eğitim sistemleri ile kıyaslaması adına bu sınavların önemli olduğuna, küreselleşen dünyada bu kıyaslamalara ihtiyaç duyulduğuna değinmişlerdir. Türkiye'nin PISA ve TIMMS sınav sonuçları bağlamında başarısız olduğunu dile getiren bazı milletvekilleri; uluslararası sınav sonuç raporlarının eğitim politikalarının iyileştirilmesinde önem arz ettiğini dile getirmişlerdir.

\section{Koşullu Kabul}

Görüşmeye katılım sağlayan milletvekillerinin uluslararası politikalar alt temasında bahsettikleri diğer bir konu koşullu kabuldür. Koşullu kabul ile ilgili olarak açıklamalardan bazıları şu şekildedir:

Farklı bir ülke tarafindan gerçekleştirilen yabancı bir sınavinın Türk eğitim politikalarına ve Türk eğitim sistemine yansıması gerekli değildir. Türkiye öyle büyük bir devlettir ve hatta öyle geniş bir kültürel yaplya sahiptir ki; kendi eğitim sistemini ve sinavını kendisi uyarlayabilir. Özellikle eğitim kültürümüzün çok eski bir tarihe dayanması bizim köklü bir devlet olduğumuzu göstermektedir. Tabii ki bu slnavların pozitif yanları, eğitim sistemimize güncelleme olarak sunulabilir. Fakat köklü değişikliklerin yapılması bence uygun değildir. (M2)

PISA ve TIMMS gibi sınavların ülkemiz eğitim sistemi ile karşılaştırılmasının yapılması ve ülkemiz eğitim uygulamalarına yansitılmasının uygun olacağı kanaatindeyim. Fakat bu sınav sonuçlarının değerlendirilerek eğitim sistemimize katkı sağlaması için bazı düzenlemelerin yapılmasl şarttır. Direk uygulamalartn eğitim sistemimize monte edilmesinden ziyade uyarlama çalışmalarına ağırlık verilmesi gerekmektedir. (M3)

Türk eğitim politikalarında değiş̧ikliğe gidecekse, bu değişikliklerin toplumun temel yapı taşlarını bozmaması gerekmektedir. Aynı zamanda yozlaşmaya sebebiyet vermemelidir... (M4)

Uluslararası sınav sonuçlarının ülkemiz eğitim sistemi ve politikalarının güncellenmesi için ön koşul olması gerekmektedir. Bu ön koşullar neticesinde ortaya çıkan gereksinimler, Türk eğitim politikasında öncelikleri oluşturmalıdır ve eksik yönlerimizi telafi etmelidir. (M5)

Açıklamalar neticesinde milletvekillerinin görüşleri incelendiğinde uluslararası sınavlar alt temasında koşullu kabul ile ilgili olarak; uluslararası sınav sonuçlarının olumlu yönlerinin eğitim politikalarımızda güncellemeler yapabileceğine fakat köklü değişiklikler yapmasına müsaade edilmemesi gerektiğine değinilmiştir. Bununla beraber PISA ve TIMMS gibi sınav sonuçlarının düzenlenmeden direk olarak değil, güncellemeler yapılarak Türk eğitim politikalarına yansıtılması gerektiğine değinen milletvekilleri; Türk eğitim politikalarında bu sınav sonuçları neticesinde değişikliklere gidilecek ise toplumun temel değerlerine ve inançlarına zarar verilmemesi gerektiğine, aksi taktirde toplumda yozlaşmaların olabileceğine değinilmişlerdir. Aynı zamanda uluslararası sınav sonuçlarının Türk eğitim politikalarının oluşturulmasında ön koşul olabileceğine de dikkat çekilmiştir.

\section{Öğretmenlerin İstihdam Politikaları}

Araştırmada öğretmenlerin istihdam politikaları alt temasının akademik başarının azalması, arz talep dengesinin gözetilmesi ve kültürel aidiyet kodları ilişkilendirildiği görülmektedir. Şekil 5'te kodlar şu şekilde gösterilmektedir: 


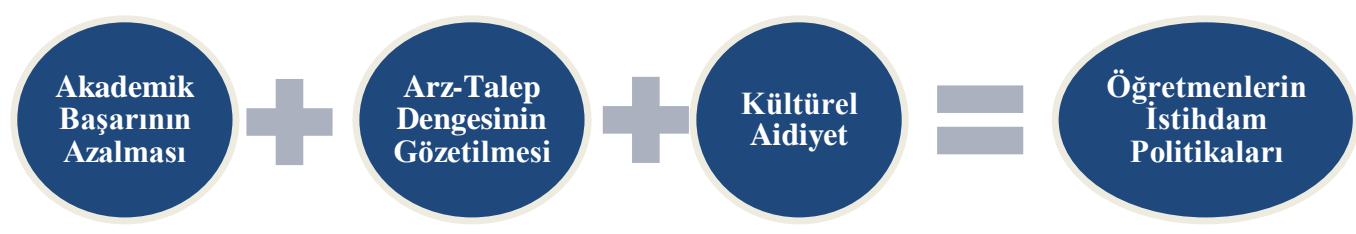

Şekil 5: Öğretmenlerin İstihdam Politikaları Kodları

\section{Akademik Başarının Azalması}

Görüşmeye katılım sağlayan milletvekillerinin öğretmenlerin istihdam politikaları alt temasında üzerinde önemle durdukları ve sıklıkla tekrar ettikleri ilk konu akademik başarının azalmasıdır. Akademik başarının azalması ile ilgili olarak açıklamalardan bazıları şu şekildedir:

Bundan yakın bir süre öncesine kadar mevcut atama istihdam politikalarinda atanan ögretmenlerin atandıkları okullarda kalma süreleri ve tayinleri ile ilgili doğu illerinde sıkıntılar yaşanıyordu... Bu durum doğal olarak özellikle ilköğretim seviyesindeki ögrencilerin akademik başarllarını olumsuz yönde etkiliyordu. Değişen öğretmen istihdam politikalarl bu durum ortadan kaldırlldı. Artık atama yapılmadan önce ögretmen atanacă̆ okulda ne kadar kalacă̆ını biliyor, ne kadar hizmet etmesi gerektiğini biliyor... (M1)

Öğretmenlerin atandıktan sonra "Artık öğretmen oldum, emekli olana kadar ders anlatsam da anlatmasam da maaşımı alacă̆ım” mantığıyla çalışmaması gerekir. İdealist olan ögretmen adaylarından ögretmenlerin seçilmesi gerekmektedir. Öğrendiklerini gerçekten öğrencilere anlatma niyetinde olan öğretmen adaylarının istihdam edilmesi gerekir. Öğrencilerini gerçekten bir yerlere getirme çabast içerisinde olan ögretmenlerin adaylarının atanması gerekir... (M2)

Türkiye'de öğretmen adaylarının kişilik erozyonuna uğradığını düşünmekteyim. Dolayısıyla akademik gelişim ikinci kriter noktası olmaktadır. Öğretmen adayları dört yllık ĕgitim serüvenleri içerisinde nitelikli eğitim öğretim faaliyetlerinden ziyade, "acaba atanabilecek miyim?" kaygısı ile eğitim almaktadırlar. Dört yıllık ĕgitimleri ise birkaç saatlik sınav olan KPSS sinavi ile test edilmekte ve atamalarl aldıkları bu puanlar ile yapılmaktadır. Aynı zamanda gerçekleştirilen atamalar ögretmenin istediği bölgelere değil, devletin yönlendirdiği bölgelere yapllmaktadır. Bu sebeple ögretmenlerin performanslarının yükselmediğini ve belirli bir seviyede kaldı̆̆ın söylemek gerekmektedir. Öğretmenin tam nitelikli bir şekilde derse konsantre olamaması, ögrencilerin akademik başarısını negatif yönde etkilemektedir. (M3)

Öğretmenlerin bölgeleri ve bölge öğrencilerini tanımamasından kaynaklı akademik problemlerin olduğunu görüyoruz. Öğretmenler atandıklarl bölgeleri, bölgelerin coğrafi yapısını, bölge insanlarının kültürel ve manevi özelliklerini tanımıyor ki, ögrenciyi nasıl tanisın? Öğretmen ögrencilerini tanımaz ve sadece laf olsun diye atamalar yapılırsa doğal olarak öğrencilerin akademik başarısı düşecektir. Özellikle eğitimde firsat eşitliğini düşünecek olursak her bölgedeki ögrencilerin eşit şekilde eğitim alması ve aynı seviyedeki ögretmenlerden istifade etmesi gerekmektedir. (M4)

Açıklamalar neticesinde bir kısım milletvekilinin görüşleri incelendiğinde öğretmenlerin istihdam politikaları alt temasında akademik başarının azalması ile ilgili olarak; atama süreçlerinde doğu illerinde yaşanan sirkülâsyonlardan dolayı özellikle ilköğretim seviyesindeki öğrenciler başta olmak üzere tüm öğrencilerin akademik başarısının azaldığına, öğretmenlerin istihdam edildikten sonra gevşediğine ve derslerinde efektif öğretim yöntemlerini kullanmadıklarına, bu neticede de öğrencilerin salt bilgiler ile donatıldığına değinilmiştir. Bununla beraber öğretmenlerin istihdam 
süreçlerinde kişilik problemleri yaşadıklarını dile getiren bazı milletvekilleri; öğretmen adaylarının dört yıl boyunca atanabilmek adına KPSS odaklı eğitim aldıklarını, bu sebeple de istihdam edildikten sonra sinıflara tam donanımlı ve aktif bir şekilde gidemediklerini, aynı zamanda bölgeleri, insanları ve en önemlisi öğrencileri tanımadıklarından dolayı akademik başarının düştüğüne değinmişlerdir.

\title{
Arz-Talep Dengesinin Gözetilmesi
}

Görüşmeye katılım sağlayan milletvekillerinin öğretmenlerin istihdam politikaları alt temasında üzerinde önemle durdukları bir diğer konu da arz-talep dengesinin gözetilmesidir. Arztalep dengesinin gözetilmesi ile ilgili olarak açıklamalardan bazıları şu şekildedir:

\begin{abstract}
Ülkemizin hem kamu okullarında hem de vakıf teşebbüsleri ile açılan eğitim kurumlarında öğretmenlere ihtiyaç duyulmaktadır. Bu ihtiyaçlar belirlenerek eğitim fakültelerine ögrenci alım sinırl getirilmesi hem nitelik problemlerini ortadan kaldıracak hem de istihdamın düzenli yapılmasını să̆layacaktır. Öğretmen istihdamının sağlanmasında mevcut hükümetler içinde en fazla atamayı gerçekleştiren, en fazla ögretmen istihdamını să̆layan, özel okulların açılmasını teşvik ederek hem kamusal alanda hem de özel sektörde ögretmenlik mesleğinin canlanmasını să̆layan bir siyasi yapıya sahibiz. Her yıl hemen hemen 5 bin ile 20 bin arasında ögretmen alımı yapıyoruz. Ülkemizin doğusu ve batısı ile ayrım göz etmeden ihtiyaca yönelik atamaları gerçekleştiriyoruz... (MI)
\end{abstract}

Maalesef ki ihtiyacımız kadar mezun veremiyoruz. Ihtiyaçlarımızdan çok fazlasını mezun ediyoruz. Bu da ögretmenlik mesleğinde istihdam slkntıların yarattyor. Özellikle ögretmen istihdamı noktasinda yeteri kadar mezun verirsek problemi çözebiliriz. Bunun yolu da stratejik planlar yaparak yeteri kadar eğitim fakültesi açmak ve fakültelere yeterli sayıda ögretmen adayı almaktan geçiyor. (M2)

460.000 civarında atanmayan ögretmen var. Siz 100.000 civarında ücretli öğretmen çalıştırlyorsunuz. Yani öğretmene ihtiyacınız var ama bunu ücretli ögretmenlik ile karşıllyorsunuz. Bu tamamen öğretmenin sırtından para kazanma zihniyetidir. Bu zihniyet çürük bir zihniyettir. Milli Eğitim Bakanının açıklamasına göre, 117.000 ögretmen ihtiyacı vardır. Bizim kendi içimizde yaptı̆̆ımı tespitlere göre, 180.000 civarında ögrretmen ihtiyacı vardır. Sayıştayın raporlarına göre 153.640 ögretmen açı̆̆ var. Varsayalım ki Milli Ĕ̈itim Bakanlı̆̆ının verdiği rakam doğrudur. O zaman ata bu kadar ögrretmeni, problem çözülsün. (M5)

Açıklamalar neticesinde bir kısım milletvekilinin görüşleri incelendiğinde öğretmenlerin istihdam politikaları alt temasında arz-talep dengesinin gözetilmesi ile ilgili olarak; hem kamu hem özel eğitim kurumlarında öğretmen ihtiyacının olduğuna, bu ihtiyaçların giderilmesi için eğitim fakültelerine ihtiyaçlar kadar öğretmen adayının alınması gerektiğine ve bu neticede mezun olacak öğretmen adaylarının istihdam sıkıntısı yaşamasının önüne geçileceğine değinilmiştir. Türkiye'de eğitim fakültelerinin ihtiyaçtan fazla mezun verdiğine, bu durumun istihdam problemlerine yol açtığına değinen bazı milletvekilleri; stratejik planlar yapılarak yeterli sayıda eğitim fakültesi açılması gerektiğini ve yeteri kadar öğretmen adayının bu fakültelerde eğitim alması gerektiğini dile getirmişlerdir. Atama bekleyen öğretmen sayısı kadar ücretli olarak görev yapan öğretmen sayısının da bir hayli fazla olduğunu dile getiren bazı milletvekilleri, ücretli öğretmenlik uygulamasına son verilerek yerine kadrolu öğretmenlerin atamalarının yapılmasa dikkat çekmişlerdir.

\section{Kültürel Aidiyet}

Görüşmeye katılım sağlayan milletvekillerinin öğretmenlerin istihdam politikaları alt temasında bahsettikleri bir diğer konu da kültürel aidiyettir. Kültürel aidiyet ile ilgili olarak açıklamalardan bazıları şu şekildedir: 
Öğrencilerin tam bir öğretmene alışmışken, öğretmenin eş durumundan veyahut başka bir mazeret neticesinde tayin olmasl sebebiyle yeni bir ögretmene alışmasl zaman almaktadır. Bu durum öğrenciyi negatif yönde etkilemektedir. Öğretmenler atandıkları bölgelere uyum sağlayamadıklarından dolayı bölgeleri terk etmektedirler. (M2)

Mevcut atama ve ögretmen istihdamı politikası yeniden gözden geçirilmelidir. Özellikle doğu bölgelerine atanan yeni ve pırıl pırıl öğretmenlerin kalıcılığının sağlanması adına teşvik edici unsurların ve kültürel uyum projelerinin artırlması gerekmektedir. (M3)

...öğretmenlerin, atanacakları bölge koşullarını iyi bilmesi gerekir. Ĕ̆er atandıkları yerlerde görev yapabilecek potansiyele sahip değiller ise en başında bu göreve başlatılmamalıdırlar. İstihdam sağlamak adına, görev yapamayacakları bölgelere ögretmen adaylarının gitmemesi gerekir. (M5)

Açıklamalar neticesinde bir kısım milletvekilinin görüşleri incelendiğinde öğretmenlerin istihdam politikaları alt temasında kültürel aidiyet ile ilgili olarak; öğretmen sirkülâsyonlarının öğrencilerin akademik başarısını olumsuz etkilediğine bu durumun nedeninin de öğretmenlerin atandıkları bölgelere kültürel anlamda alışamamaları olduğuna değinilmiştir. Mevcut atama istihdam politikasının gözden geçirilerek doğu illerine atanan öğretmenlerin o bölgelerde kalıcılığının sağlanması adına kültür eğitimlerinin verilmesi gerektiğine değinen bazı milletvekilleri; öğretmenlerin atanacakları bölgeleri tanıması gerektiğine, eğer bu bölgelere uyum sağlayamayacaklar ise daha en başından itibaren bu görevlere talip olmamalarına değinmişlerdir.

\section{Yöneticilerin İstihdam Politikaları}

Araştırmada yöneticilerin istihdam politikaları alt temasının liyakatin önemi, lisansüstü eğitim gereksinimi ve sendikal olumsuzluklar kodları ilişkilendirildiği görülmektedir. Şekil 6'da kodlar şu şekilde gösterilmektedir:

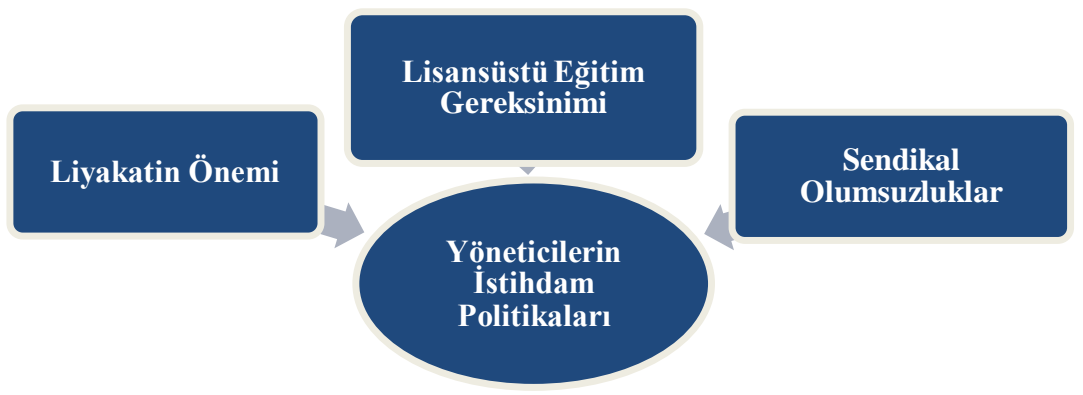

Şekil 6: Yöneticilerin İstihdam Politikaları Kodları

\section{Liyakatin Önemi}

Görüşmeye katılım sağlayan milletvekillerinin yöneticilerin istihdam politikaları alt temasında üzerinde önemle durdukları ve sıklıkla tekrar ettikleri ilk konu liyakatin önemidir. Liyakatin önemi ile ilgili olarak açıklamalardan bazıları şu şekildedir:

Ülkemizde sadece milli eğitim sistemi içerisinde yönetici atamalarında değil, genel olarak bütün kamu kurumlarının yönetici atamalar noktasında liyakat sisteminin tekrardan önem kazanması ümidindeyim. Yönetici atamalarının siyasi bir kaliptan çılkarllıp ögretmenler arasından nitelikli sahibi olanların idareci olarak atanmasının sağlanmast gerekmektedir. Siyasi atamaların bir kenara bırakllmast ivedi bir şekilde sağlanmalıdır. Liyakatin ön planda tutulması gerekmektedir.(M2)

Türkiye'de gerçekleştirilen eğitim yöneticisi atamaları liyakate bağlı olarak yapılmıyor. Eğitim yöneticileri yani okul müdürlerinin ve yardımcılarının atamalarının düzene girmesi için objektif değerlendirmelerin sağlanması gerekir. Maalesef ki hükümetin talimatı ile yetkili sendika referanslı atamaların gerçekleştiğini görüyoruz. (M3) 
Demokratik ülkeler, insanların iradesine önem verirler. Merkezden atamalara çok olumlu bakmazlar. Türkiye'de maalesef, "bana itaat edersen, seni daha yüksek mevkilere getiririm" politikası var. Bakıyorsunuz eğitimle hiç alakası olmayan insanlar eğitim sisteminin tepesine getiriliyor. Doğal olarak burada kötü sonuçlar ortaya çıkıyor. Özellikle yönetici atama sürecinde; ĕgitimi bilen, ĕgitimin içerisinden gelen kişilerin atamasına önem ve özen gösterilmelidir. Okullart bilmeyen, öğrencilerin yapısını iyi analiz edemeyen, milli ĕgitim sistemini tanımayan yönetici adayları ĕ̆itim sistemine daha da zarar verecektir. Liyakate önem verilmeli ve eğitimin içerisinden gelecek ögrretmenler yönetici olmalıdırlar.(M4)

Okul yöneticisi olarak adlandırdığımız müdür ve müdür yardımcılarının atamaları mülakata göre değil liyakate göre olmalıdır. Siyasi sistemin ve düzenin iki dudak arasına sıkıştırılmış atamaların hiçbiri liyakate uygun değildir. Liyakatsiz eğitim yöneticisi atamaları maalesef eğitim sistemimizi ve okullarımızı bu hale getirmiştir... (M5)

Açıklamalar neticesinde bir kısım milletvekilinin görüşleri incelendiğinde yöneticilerin istihdam politikaları alt temasında liyakatin önemi ile ilgili olarak; sadece eğitim yöneticilerini belirlerken değil tüm kamu kurumlarında yöneticilerin belirlenmesi sürecinde liyakat temelli atamaların yapılması gerektiğine; eğitim yöneticisi atamalarının siyasi kalıplardan çıkarılarak, liyakat sisteminin ön plana alınması gerektiğine değinilmiştir. Türkiye'de eğitim yöneticisi atamalarının objektif, tarafsız ve liyakat temelli yapılmadığına değinen bazı milletvekilleri; atamaların hükümet talimatları ile yetkili sendikaların görüşleri alınarak yapıldığına, demokratik ülkelerde bu durumun yaşanmadığına ve insanların iradesine daha fazla önem verildiğine değinmişlerdir. Merkezi atamaların liyakati temelden sarstığına değinen bazı milletvekilleri; eğitim yönetimi ile alakası olmayan öğretmenlerin idareci yapılmasının milli eğitim sistemini de etkileyeceğini dolayısı ile mülakata göre değil liyakate göre atamaların yapılması gerektiğine değinmişlerdir.

\section{Lisansüstï Eğitim Gereksinimi}

Görüşmeye katılım sağlayan milletvekillerinin yöneticilerin istihdam politikaları alt temasında üzerinde önemle durdukları bir diğer konu da lisansüstü eğitim gereksinimidir. Lisansüstü eğitim gereksinimi ile ilgili olarak açıklamalardan bazıları şu şekildedir:

Yönetici atamaları yapılırken öğretmen fakültesi mezunu olma şartı getirilebilir. Aynı zamanda yüksek lisans ve doktora ĕgitimlerini yönetici olma kriteri olarak koyabiliriz. Yöneticilik üzerine, eğitim yönetimi ve denetimi alanında lisansüstü eğitim yapan ögretmen adayları arasından idareciler seçilebilir. (M2)

...alınan yüksek lisans ve doktora eğitimleri ve motivasyonun da göz önünde bulundurulması gerektiğini düşünüyorum. Tek bir sınava bağlı kalarak ögretmenler arasından yönetici atamalarının yapılmaması gerekir. (M3)

Yönetici atama süreçlerinde özellikle kariyer yapmış, okulların beklentilerini bilen ögretmenler arasından seçimler yapılmalıdır... (M5)

Açıklamalar neticesinde bir kısım milletvekilinin görüşleri incelendiğinde yöneticilerin istihdam politikaları alt temasında lisansüstü eğitim gereksinimleri ile ilgili olarak; yüksek lisans ve doktora eğitimlerinin (lisansüstü eğitimlerin) yöneticilik süreçlerinde kriter olarak konulabileceğine ve yöneticilik üzerine lisansüstü eğitim almış veyahut almayı kabul eden öğretmenler arasından eğitim yöneticilerinin seçilebileceğine değinilmiştir. Tek bir sınav ve ya da sadece mülakat ile yönetici görevlendirmelerinin yanlış olduğuna değinen bazı milletvekilleri, yönetici atama süreçlerinde özellikle kariyer yapmış ve motivasyonu yüksek öğretmenlerin ön planda olması gerektiğine dikkat çekmiş̧lerdir. 


\section{Sendikal Olumsuzluklar}

Görüşmeye katılım sağlayan milletvekillerinin yöneticilerin istihdam politikaları alt temasında bahsettikleri diğer bir konu da sendikal olumsuzluklardır. Sendikal olumsuzluklar ile ilgili olarak açıklamalardan bazıları şu şekildedir:

Mülakatlarda sendikaya bağll idarecilerin mülakatları gerçekleştirdiğini ve yönetici atamalarının bu referanslar ile olduğunu görmekteyiz. Sendika referanslı atamalardan vazgeçilmeli, eğitim yöneticilerinin seçiminde liyakat esas alınmalıdır. (M3)

Okullarımıza sadece tek bir sendika yönlendirilmesiyle yönetici atamaların gerçekleştiğini görüyoruz. Bu pek ümit verici bir durum değildir. (M4)

Günümüzde sendikaya göre; yani sadakate göre atama yapılmaktadır. Bizim zamanımızda devlet güdümlü sendikalar vardı. Şimdi hükümet güdümlü sendikalar var. (M5)

Açıklamalar neticesinde bir kısım milletvekilinin görüşleri incelendiğinde yöneticilerin istihdam politikaları alt temasında sendikal olumsuzluklar ile ilgili olarak; yönetici mülakatlarında elemeleri yetkili sendikalara bağlı idarecilerin yaptığı, bu neticede kendi sendikalarına üye olan öğretmenleri yönetici olarak seçtikleri dile getirilmiştir. Eğitim yöneticiliğinin tek bir sendikaya bağlı kalarak belirlenmesinin problemlere sebebiyet vereceğini dile getiren bazı milletvekilleri; sendikaların daha eskiden devlet güdümlü olduğunu, günümüzde ise hükümet güdümlü çalışma sergilediklerini aktarmışlardır.

\section{Müfredatın Ulusal Değerlere Yansıması}

Araştırmada müfredatın ulusal değerlere yansıması alt temasının müfredatın yetersizliği, uygulama eksikliği ve kültürel erozyon kodları ile ilişkilendirildiği görülmektedir. Şekil 7'de kodlar şu şekilde gösterilmektedir:

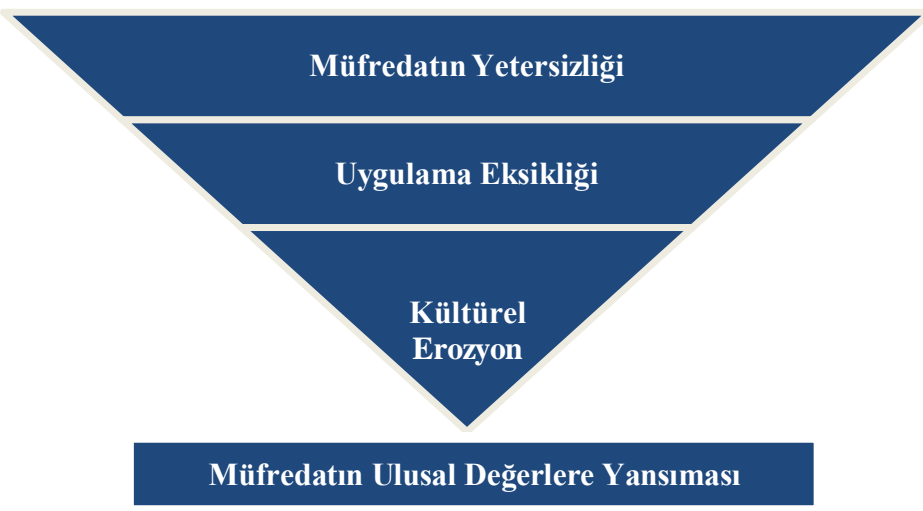

Şekil 7: Müfredatın Ulusal Değerlere Yansıması Kodları

\section{Müfredatın Yetersizliği}

Görüşmeye katılım sağlayan milletvekillerinin müfredatın ulusal değerlere yansıması alt temasında üzerinde önemle durdukları ve sıklıkla tekrar ettikleri ilk konu müfredatın yetersizliğidir. Müfredatın yetersizliği ile ilgili olarak açıklamalardan bazıları şu şekildedir:

Türk eğitim müfredatının tam olarak amaca hizmet ettiğini söyleyemem. Ancak istikrarlı politikalarla nihai hedefe ulaşılabileceğini düşünüyorum. Türk eğitim sistemindeki en büyük sikıntılardan biri ahlak ve maneviyat. Bu sikintıları çözmenin bir yolu müfredatımızın güncellenmesinden; ahlaki değerlere, aile yapısının düzenlenmesini içeren derslere önem verilmesinden; büyüklere saygl, küçüklere sevgi davranışlarının ögretilmesinden geçmektedir. Kısacası ögrencilere sadece akademik bilgi ve birikimlerin değil; kültürel ve ahlaki değerlerin de hem örtük olarak, hem de içerik 
olarak ĕgitim sisteminde verilmesi gerekmektedir. Mevcut ĕ̆itim müfredatının şuan ülkemizin kültürel ve ahlaki değerlerini yansıttı̆̆ını düşünmüyorum. (M1)

Şu an mevcut eğitim müfredatının Türkiye'nin kültürel ve ahlaki değerlerini tam olarak yansittı̆̆ını söyleyemeyeceğim. Fakat bir değişim süreci içerisinde olduğumuz için ümitliyim. Genel olarak görüşümü ifade edecek olursam; Türk genci kendi kültürünü, kendi ahlakını, kendi örf adetlerini eğitim sistemi içerisinde almalıdır. Türk töresinde Islam kültürü hiçbir zaman geri planda bırakılamaz. Çocuklarımızın ve gençlerimizin tarihini öğrenmesi, kendini bilmesi her zaman eğitim sistemi için olumlu etkiler yaratacaktır. (M2)

Türk ĕgitim müfredatını incelediğimde maalesef ezberci bir ĕgitim sisteminin hedef güdüldüğ̈̈nü görmekteyim. 16 yıldır yap-boz gibi her bakan değişiminde yeni bir müfredat uygulanmaya konulmaya çalışılmış ve başarısız sonuçlarla karşılaşılmıştır. Öğrencilerimizin okullarda uygulamadan uzak, pratik yapmaktan uzak sadece teorik bilgilerle donatılması çok sıkıntılı süreçtir. Öğrencilerin psikolojik ve sosyal gelişimlerinin desteklenmediği Milli eğitim müfredatının başarılı olması beklenemez. 16 yılı aşkın bir süredir değişen Milli Eğitim Bakanlık kadroları sebebiyle milli ve ahlaki değerler gözardı edilmiştir. Okullarımızda öğrencilerin denge problemi yaşaması, kavgaların sılklkla oluşması, hatta ve hatta cinayetlerin ortaya çıkması bu sebeplerden kaynaklanmaktadır. Toplumun refah seviyesini artırmak adına gerçekleştirilen eğitim firsatları maalesef ki tam bir fiyaskodan ibarettir. (M3)

Açıklamalar neticesinde bir kısım milletvekilinin görüşleri incelendiğinde müfredatın ulusal değerlere yansıması alt temasında müfredatın yetersizliği ile ilgili olarak; Tük eğitim müfredatının amaçlara hizmet etmediğine, ülkede genelindeki ahlak ve maneviyat problemlerinin müfredatın yetersizliğinden dolayı oluştuğuna fakat istikrarlı eğitim politikaları ile bu durumun üstesinden gelinebileceğine değinilmiştir. Mevcut eğitim müfredatının ülkenin ahlaki ve kültürel değerlerini yansıtmadığını dile getiren bazı milletvekilleri; değişim sürecindeki Türkiye'de oluşturulacak yeni eğitim müfredatından ümitli olduklarını, Türk eğitim sisteminde Türk-İslam sentezinden vazgeçilemeyeceğine ve öğrencilerimizin kendilerini ve tarihini bilmesi gerektiğine vurgu yapmışlardır. Aynı zamanda eğitim müfredatının ezberci bir yapıda olduğuna değinen bazı milletvekilleri; değişen hükümetlerin ve bakanların eğitim müfredatını da değiştirmeye kalktıklarına, bu neticede de müfredatta istikrarın bir türlü yakalanamadığına dikkat çekmişlerdir.

\section{Uygulama Eksikliği}

Görüşmeye katılım sağlayan milletvekillerinin müfredatın ulusal değerlere yansıması alt temasında üzerinde önemle durdukları bir diğer konu da uygulama eksikliğidir. Uygulama eksikliği ile ilgili olarak açıklamalardan bazıları şu şekildedir:

Ĕ̆itim milli değerleri özümseyen ve gelecek nesillere eğitim hizmeti veren okullar, eğitim kurumlarl, uygulamalar, politikalar olursa milli hedeflere ulaşma noktasında da kolaylık sağlanmış olur. Talim Terbiye Kurulundaki değişimler, okul ders kitaplarının yeniden düzenlenmesi, güncel ders müfredatlarının incelenmesi ve kültürümüzden daha fazla veriler ve doneler içermesi milli hedeflere ulaşmamıza vesile olmaktadır. Fakat ögrencilere sadece akademik bilgi ve birikimlerin değil; kültürel, ahlaki değerlerin de hem örtük olarak, hem de içerik olarak ĕgitim sisteminde verilmesi gerekmektedir. (M1)

Ahlak kavramının oldukça eski eskidir. Temel ahlak kurallarının aktarılmasında müfredattan beklenenler, son yllarda yerine getirilmektedir. Fakat ahlak kavramının yalnızca müfredatta yer alması ögrencilerimizin benimsemesi için yeterli olmayabilir. Bu noktada toplum ve aileler devreye girmeli ve ahlak kavramının küçük yaşlarda verilmesi să̆lanmalıdır. (M2)

Türk eğitim müfredatımızı incelediğimde ezberci bir eğitim sisteminin hedef güdüldügünü görmekteyim... Öğrencilerimizin okullarda uygulamalardan uzak, pratik yapmaktan uzak, sadece teorik bilgilerle donatılması çok sıkıntılı süreçtir. (M5)

Turkish Studies - Education, 15(3) 
Açıklamalar neticesinde bir kısım milletvekilinin görüşleri incelendiğinde müfredatın ulusal değerlere yansıması alt temasında uygulama eksikliği ile ilgili olarak; milli hedeflere ulaşma noktasında değerleri özümseyecek ve uygulayacak okullar ve politikaların işi kolaylaştıracağına, eğitim sisteminde yaşanan gelişmelerin Türk eğitim politikalarına olumlu yansıyacağına, kültürel ve ahlaki değerlerin eğitim isteminde hem içerik olarak hem örtük bir şekilde verilmesi gerektiğine değinilmiştir. Ahlak kavramının çok eski bir kavram olduğuna değinen bazı milletvekilleri, temel ahlak kurallarının aktarımının son yıllarda müfredatta gerçekleştiremediğine bu noktada toplumunda bu ahlak kurallarının uygulayıcısı ve denetleyicisi olması gerektiğine ve ezberci müfredatın okullarda uygulamalı eğitimler ile desteklenerek güncellenmesi gerektiğine değinilmiştir.

\title{
Kültürel Erozyon
}

Görüşmeye katılım sağlayan milletvekillerinin müfredatın ulusal değerlere yansıması alt bahsettikleri diğer bir konu da kültürel erozyondur. Kültürel erozyon ile ilgili olarak açıklamalardan bazıları şu şekildedir:

\begin{abstract}
Bizim zamaninda okutulan edebiyat kitaplart vardl. Biz bu kitaplarda her türlü kendi özümüzde ilgili bilgileri alabiliyorduk. Ama daha sonraki süreçlerde yavaş yavaş Milli eğitim müfredatlarında kültürel bozulmalar meydana geldi. Bunlardan bir tanesi andımızın kaldırılmasıdır. Andımızın okunmasında Türk çocukları için bugüne kadar kötü hiçbir şey göremedik. Türküm, doğruyum, çallşsanım... Çocukların bunları söylemesi ve and içmesi gayet doğaldır. Türk çocuğunun okullara başlarken and içmesinin içerisinde asla kötü ya da ırkçı bir durum görmedik. (M2)
\end{abstract}

Okullarımızda ilk önce ahlaki ve milli değerlerin kazandırlması sağlanmalıdır. Sonra teorik bilgileri verilmelidir. Ĕger kültürel ve ahlaki değerleri geri plana atacak olursak diğer toplumlar tarafindan yönetilmeye ve idare edilmeye muhtaç kalırı. (M3)

Eğitim politikalarıtopl umun temelinden destek görmediği için, şiddete meyilli bireyler okullarımızda yetişmektedir. Bu kültürel bozukluklar maalesef ki çok küçük yaşlara inmiştir. İşte bu ahlak bozukluğu ve kültürel değerlerin yok olmasl, insanların birbirlerine karşı bakış açısının farklılaşmasından kaynaklanmaktadır. (M2)

Açıklamalar neticesinde bir kısım milletvekillerinin görüşleri incelendiğinde müfredatın ulusal değerlere yansıması alt temasında kültürel erozyon ile ilgili olarak; eskiden titizlik ile verilen eğitimlerin günümüzde verilmediğine, bu sebep ile toplumda kültürel bozulmaların meydana geldiğine, çocuklarımızın milli, kültürel ve ahlaki değerlerini kaybettiklerine bu sebep ile müfredatta değerler eğitimine öncelik verilmesi gerektiğine değinilmiştir. Okullarda teorik bilgilerden önce değerlerin öğretilmesi gerektiğine değinen bazı milletvekilleri; eğitim politikalarının toplumun bütün kesimlerinden destek görmesi gerektiğini, aksi halde kültürel bozukluklar, ahlaki değer yoksunlukları ve önyargıların oluşacağına dikkat çekmişlerdir.

\section{Sonuç ve Tartışma}

Türk eğitim politikalarının belirlenmesinde, bu politikalar ile uzun ve kısa vadeli hedeflerin planlanmasında ve bu hedeflerin eğitim sisteminde devamlılığının sağlanmasında hiç şüphesiz en büyük yetki TBMM milletvekillerindedir. Bu sebeple yasama erki konumundak milletvekillerinin Türk eğitim politikaları ile ilgili algılarının eğitim sistemi yönetimine yön verdiği görülmektedir.

Araştırma bulguları incelendiğinde; TBMM milletvekillerinin hükümet ve muhalefet partilerine mensup olmalarına göre görüşlerinin de farklılık gösterdiği ortaya çıkmaktadır. Bu durum; TBMM milletvekillerinin ait oldukları siyasi partilerin ideolojilerini kendi kişisel görüşlerinden daha ön planda tuttuklarının göstergesidir. Mevcut araştırmada TBMM milletvekillerinin algıları neticesinde Türk eğitim politikaları; öğretmen yetiştirme politikaları, uluslararası sınavlar, öğretmenlerin istihdam politikaları, yöneticilerin istihdam politikaları ve ulusal değerlerin müfredata yansıması ile ilişkilendirilmiştir. 
Araştırma bulgularında öğretmen yetiştirme politikaları genel olarak niteliksel sorunlar, pedagojik formasyon, ideolojik yönelimler ve teorik yönelimler ile bağdaştırılmışıtır. Her bireyin öğretmenlik yeteneği olmayabilir. Çünkü öğretmen olabilmek için sabır ve özveri gibi birçok özelliğin bireylerde bulunması gerekir. Fakat Türkiye'de öğretmenliğin garanti bir meslek olarak görülmesi eğitim fakültelerinin tercih sebebi olmasına neden olmaktadır (Işık vd., 2011). Bursalığlu (2011: 41) okulların en stratejik parçasının öğretmenler olduğunu fakat tarihten beri öğretmen yetiştirme alanında uygulanan kriterlerin genel olarak çelişkili, karmaşık ve yetersiz kaldığına değinmiştir. Öğretmenliği seçen öğrencilerin öğretmenlik mesleği, genel kültür ve alan bilgisi kazanmaları beklenir (Yazıcı, 2009). Araştırma bulgularında pedagojik formasyon eğitimleri diğer bir sorundur. 1990'lı yılların ortalarında gerçekleştirilen herhangi bir lisans bölümünden mezun olan bireylerin öğretmenlik eğitimi almadan istihdam edilmesi öğretmenliğe yönelik toplumun olumsuz yargılar oluşturmasına neden olmuştur (Yıldırım, 2011). Yine bulgularda ideolojik yönelimler ile ilgili olarak her yeni gelen hükümetin ve bakanın kendi eğitim politikalarını uygulamaya kalkmasının hata olduğuna değinilmiştir. Ayas (2009) önemli olanın eğitim uygulamalarında süreklilik sağlamak olduğunun, çalışmaların yap-boz tahtası gibi değiştirilmesinin etkili olmadığına, gerçekleştirilen çalışmaların yeterli sürelerde uygulanması ve bilimsel araştırmalar ile değerlendirilmesinin isabetli kararlar almak için gerekliliğine değinmiştir. Araştırma bulgularında öğretmenlik derslerinde uygulamalı derslerden ziyade teorik derslerin verildiğine, bu durumun öğretmenleri salt bilgilerle doldurduğuna değinilmiştir. Türkiye'de uygulanan öğretmenlik programlarındaki derslerde uygulamaya ağırlık gösterilmesi ve özel bir önem verilmesi, derslerin daha çok genel kültür ve uygulamalı öğretmenlik derslerine dönüştürülmesi gerekmektedir (Başkan vd., 2006). Öğretmenlerin yetiştirilmesi politikalarında gerçekleştirilmesi gereken temel vizyon ve misyon Türkiye olarak öğretmenlerin eğitimi konusunda yenilenmek ve bu yeniliklere bağlı milli politikalar üretmektir (Ayas, 2009).

Mevcut araştırma bulguları incelendiğinde uluslararası sınavların genellikle eğitimin önemi, eğitim politikalarının iyileştirilmesi ve koşullu kabul ile bağlantılı olduğu görülmektedir. Yıldırım (2009) araştırmasında PISA sınavı sonuçlarına bağlı olarak Türkiye'de eğitimin kalitesini belirleyen etmenlerin sosyo-kültürel ve sosyo-ekonomik faktörlerden biri olan yaşam bölgesi, ebeveynlerin eğitimleri ve ekonomik durumlar olduğunu aktarmaktadır. Uluslararası sınavlardan biri olan TIMMS sınavı; öğrenci başarı durumlarının karşılaştırılması, başarılı ülkelerin başarı etmenlerinin analiz edilmesi ve bu ülkelerin eğitim politikalarında ne uygulamalar ve değişiklikler olduğu üzerine pek çok konuda karşılaştırmalar yapılmasına ve eğitim problemlerinin çözülmesine destek olmaktadır (Yılmaz vd., 2016) . Özcan ve Koştur (2019) uluslararası sınavların önemi ve eğitim politikalarına yansıma ile ilgili olarak ilk önce bu sınavlarda başarı yakalayan ülkelerin eğitim sistemlerinin ve öğretmen niteliklerinin incelenmesi gerektiğine, buna bağlı olarak da ülke şartlarını göz ardı etmeden eğitim politikalarında köklü değişiklikler yapılabileceğine değinmişlerdir. Uluslararası sınavlar kadar ulusal raporların da incelenerek, eksik yönlerinin giderilmesi gerektiğine değinen Özcan ve Koştur (2019) eğitimde her adımda öğretmenlerin fikirlerinin alınması gerektiğini dile getirmiştir.

Öğretmenlerin istihdam politikalarına bakıldığında; akademik başarının azalması, arz talep dengesinin gözetilmesi ve kültürel aidiyet odaklı olduğu görülmektedir. Şahin (2011) uluslararası sınavlarda başarılı olan Singapur ve Finlandiya'nın öğretmenlik bölümlerine öğrenci seçerken ihtiyaçları kadar öğretmen adayını aldıklarına, bu seçimlerde akademik bilginin yanında öğretmenliğe duyulan ilgi, mesleki yatkınlık ve uygulamalı ders anlatımları ile öğrencilerin iletişim becerinin ölçüldügüne ve arz-talep dengesi göz önüne alınarak bu bölümlere seçilen öğrencilerin mezun olduklarında ikinci bir elemeye tabi tutulmadan atanabildiklerine değinmiştir. Safran vd. (2014) göre öğretmenlerin istihdam politikaları oluşturulurken eğitim fakültesinden mezun olanların öncelikli bir şekilde tercih edilmesi gerektiği dile getirilmiştir. Yine Şahin (2011) öğretmenlerin farklı nedenlere bağlı olarak eğitim sistemi içerisinde yer değiştirdiklerine, genellikle de doğudan batıya doğru bir sirkülâsyonun olduğuna, bu sebeple de doğu illerinde ve 
kırsal kesimde öğretmen açıklarının oluştuğuna ve bu açığın tecrübesiz, formasyon bilgisi olmayan ücretli ve vekil öğretmenler ile kapatılmaya çalıştığını aktarmıştır. Araştırma bulgularında bu durum öğretmenlerin atandıkları bölgelere kültürel aidiyet duymaması ile açıklanmaktadır. Netice itibarı ile de öğretmen sirkülâsyonlarından dolayı eğitim çalışmalarının aksadığı, dolayısıyla öğrencilerin başarısının da düştüğü sonucuna ulaşılmaktadır. Maalesef ki Türkiye'de öğretmenlerin istihdamı konusunda geliştirilen politikalarda arz-talep dengeleri gözetilmemektedir (Şahin, 2011). Literatür incelendiğinde öğretmenlerin atama kriterleri ile ilgili olarak Koçak ve Kavak (2014) eğitim fakültelerinden mezun olan adayların atamalarda öncelikli değerlendirilmesi gerektiğini, ihtiyaçlar karşılanmadığında alan fakültesi mezunlarına yer verilmesi gerektiğini, istihdam noktasında lisansüstü eğitimin bir kriter olması gerektiğini, MEB ile YÖK'ün arz talep dengesini kurabilmek adına ortak çalışması gerektiğini önermiştir.

Araştırmada yöneticilerin istihdam politikalarının; liyakatin önemi, lisansüstü eğitim gereksinimi ve sendikal olumsuzluklar ile ilişkilendirildiği görülmektedir. Onural (2005) Milli Eğitim Bakanlığı merkez örgütlerinde eğitim yönetimi alanı ile ilgili formal eğitim almış nitelikli yöneticilerin bulunmamasının önemli bir sorun olduğuna, yönetici eğitimleri ile ilgili kararlı politikanın oluşturulamaması, yöneticilerin görevlendirilmesinde objektif ölçütlerin olmaması ve yeterli hale getirmek için de çalışma yapılmamasının yetersizliklerin temel nedenlerinden olduğunu dile getirmiştir. Aynı zamanda eğitim alanındaki yöneticilerin eğitim yönetimi alanı ile ilgili eğitimler almış olmaları görevlendirmede temel kriter olmalıdır. Milli Eğitim Bakanlığı merkez örgütlerinde görevde olan eğitim yöneticilerinin eğitim yönetimi alanı ile ilgili yeterliliklerinin arttırılması gerektiğine değinilmiştir. Araştırma bulgularında da özellikle lisansüstü eğitim ihtiyacı milletvekilleri tarafindan yöneticilerin atamalarında dile getirilmiştir. Aktepe (2014) yapmış olduğu araştırmada, okul yöneticisi olacakların alanlarında nitelikli olabilmesi adına eğitim yönetimi alanı ile ilgili lisansüstü eğitim yapmaları ve devletin de bu eğitimleri teşvik etmesi gerektiğine dikkat çekmiştir. Arabacı vd. (2015) mevcut öğretmen yetiştirme ve istihdam politikalarının sorunlarını incelediği araştırmada, Türkiye'deki mevcut atama yöntemlerinin taraflı olduğuna, eğitimin siyasi çıkar çatışmaları içerisinde olduğuna, atama yöntemlerinin şeffaflıktan uzak olduğuna, deneyimsizlik ve tecrübesizliklerin sıkıntı yarattığına ve en önemlisi sendika faktörünün yöneticilerin görevlendirilmesi hususunda en belirleyici etmen olduğunu belirtmişlerdir. $\mathrm{Bu}$ neticede göreve getirilen yöneticilerin makamın gerektirdiği yeterliliğe sahip olmadığ 1 ortaya çıkmaktadır.

Müfredatın ulusal değerlere yansımasının ise müfredatın yetersizliği, uygulama eksikliği ve kültürel erozyon ile bağlantılı olduğu görülmektedir. Akbaş (2008) okullarımızın akademik becerilerinin öğretimi ile beraber vatan sevgisi, saygı, dürüstlük ve adillik gibi kavramlarının öğretiminin de bulunduğuna değinmiş; okulların görevleri arasında müfredatta belirtilen veyahut belirtilmeyen değerlerin öğretimi, öğrencilerin disipline edilmesi ve ahlaki gelişimlerinin sağlanmasının da olduğuna dikkat çekmiştir. Aynı zamanda eğitim kurumlarının uygulamalar yaparak bu ve benzeri değerleri öğrencilere yaşatması gerektiğine değinilmiştir. Bu neticede okullarda özellikle müfredatta yer alsa da almasa da, formal veyahut informal yollar ile değerlerlerin gelecek kuşaklara aktarılmasının elzem olduğu aşikârdır. Bu neticede araştırma bulgularında da belirtildiği üzere, okullardaki disiplin problemlerinin giderilmesi, değerlerin öğretilmesi adına uygulamaların artırılması gerekmektedir. Yine araştırma bulgularında kültürel erozyonun bireylerin ahlak ve inanç değerlerini sarstığına ve örf ve adetlerini yok ettiğine değinilmiştir. Değerlerden soyutlanmış bir eğitim sistemi içerisinde, neyin yanlış neyin doğru olduğu ve neyin öğretiminin öncelikli olması gerektiğini tespit etmek zordur (Altun, 2013). Balay ve Kaya (2014) araştırma sonuçlarında değerlerin okullarda müfredatla etkin bir şekilde aktarılmadığında suç işleme sayılarının arttığını, bu tip toplumlarda boşanmaların arttığını, madde bağımlılıklarının çoğaldığını ve güvenlik sorunlarının arttığını aktarmışlardır. $\mathrm{Bu}$ durumun araştırma bulgularında kültürel erozyonun topluma yansıması olarak karşımıza çıkmaktadır. 
Sonuç olarak TBMM milletvekillerinin çoğunluğunun nitelikli Türk eğitim politikalarının oluşturulması noktasında ümitkar olduğu, fakat eğitim sistemimizde halen geliştirilmesi gereken unsurların var olduğu sonucuna varılmaktadır. Özellikle milletvekillerinin siyasi söylemlerinde Türk eğitim politikaları bağlamında ülke menfaatlerini önemsedikleri, vatandaşların çıkarlarını korudukları ve gençlerin eğitimden beklentilerini önemsedikleri görülmektedir.

\section{Kaynakça}

Adem, M. (1997). Ulusal eğitim politikamız nasıl olmalıdır? Ankara Üniversitesi SBF Dergisi, 52(1), 51-65.

Akbaş, O. (2008). Değer eğitimi akımlarına genel bir bakış. Değerler Eğitimi Dergisi, 6(16), 9-27.

Aktepe, V. (2014). Okul yöneticilerinin seçme ve yetiştirme uygulamalarına yönelik öğretmen ve $\begin{array}{lllll}\text { yönetici görüşleri. } & \text { Turkish } & \text { 89-105. }\end{array}$ http://dx.doi.org/10.7827/TurkishStudies.6207

Altun, A., S. (2003). Eğitim yönetimi ve değerler. Değerler Eğitimi Dergisi, 1(1) 7-18.

Arabac1, İ., Şanl1, Ö. ve Altun, M. (2015). Okul yöneticilerinin yetiştirilme ve atama yöntemlerine ilişsin sendika temsilcilerinin, maarif müfettişlerinin ve okul yöneticilerinin görüşlerinin değerlendirilmesi. Mustafa Kemal Üniversitesi Sosyal Bilimler Enstitüsü Dergisi, 12(31), 166-186.

Ayas, A. (2009). Öğretmenlik mesleğinin önemi ve öğretmen yetiştirmede güncel sorunlar. İnönü Üniversitesi Eğitim Fakültesi Dergisi, 10(3), 1-12.

Aypay, A. (2015). Eğitim politikası. Pegem akademi yayıncılık.

Azar, A. (2011). Türkiye'deki öğretmen eğitimi üzerine bir söylem: Nitelik mi, nicelik mi? Yükseköğretim ve Bilim Dergisi, 1(1), 36-38.

Balay, R. ve Kaya, A. (2014). Eğitim fakültesinde okuyan öğretmen adaylarının ahlaki değer yönelimleri. Değerler Ĕ̈itimi Dergisi, 12(28), 7-45.

Başaran, İ. E. (1999). Eğitime giriş. Umut Yayın Dağıtım.

Başkan, G. A., Aydın, A. ve Tuğba, Ö. (2006). Türkiye'deki öğretmen yetiştirme sistemine karşılaştırmalı bir bakış. Çukurova Üniversitesi Sosyal Bilimler Enstitüsü Dergisi, 15(1), $35-42$.

Bell, L. ve Stevenson, H. (2006). What is education policy? In Education Polic, .23-40.

Bursalığlu, Z. (2011). Okul yönetiminde yeni yapı ve davranış. Ankara: Pegem Akademi Yayınları.

Creswell, J. (2009). Research design: A qualitative, quantitative, and mixed method approaches. SAGE Publications: Incorporated.

Creswell, J. W. \& Plano Clark, V. L. (2011). Designing and conducting mixed methods research. Thousand Oaks, Sage Publications, Inc.

Çelik, V. (2003). Eğitimsel liderlik. Pegem A Yayınları.

Demirtaş, H. ve Güneş. H. (2002). Eğitim yönetimi ve denetimi sözlü̆̆̈̈. Anı Yayıncılık.

Devlet Planlama Teşkilatı. (2009). Beş Yıllık Kalkınma Planları. Web site: http://ekutupdpt.gov.tr/ plan/plan.asp. adresinden 18 Aralık 2018 tarihinde edinilmiştir.

Ekiz, D. (2003). Eğitimde araştırma yöntem ve metotlarına giriş. Anı Yayıncılık. 
Fraenkel, J. R., Wallen, N. E. \& Hyun, H. H. (2012). How to design and evaluate research in education (8th Ed.). McGram-Hill Companies.

Gibbs, G. R. (2017). Yazılım ve nitel veri analizi. J. Arthur, M. Waring, R. Coe \& L. V. Hedges (Eds.), Çeviri Editörü: A. Erözkan ve E. Büyüköksüz. Eğitimde araştırma yöntemleri ve metedolojileri (s.415-427). Anı Yayınc1lık.

Guba, E. G. (1981). Criteria for assessing the trustworthiness of naturalistic inquiries. Educational Communication and Technology Journal, 29, 75-91.

Işık, A., Çiltaş, A. ve Baş, F. (2010). Öğretmen yetiştirme ve öğretmenlik mesleği. Atatürk Üniversitesi Sosyal Bilimler Enstitüsü Dergisi, 14(1), 53-62.

Iş1k, H. (2003). Okul müdürlerinin yetiştirilmesinde yeni bir model önerisi. Hacettepe Üniversitesi Ĕ̈itim Fakültesi Dergisi, 24, 206-211.

Kapani, M. (1988). Politika bilimine giriş (4. Baskı). Bilgi Yayınevi.

Kaya, Z. (2005). Sinıf yönetimi. Pegem Akademi.

Koçak, S. ve Kavak, Y. (2014). Milli Eğitim Bakanlığının öğretmen atama esasları ve kaynak yükseköğretim programlarıyla ilgili gelişmeler. Hacettepe Üniversitesi Eğitim Fakültesi Dergisi, 29(4), 157-170.

Levent, F. (2009). Üstün Yetenekli Eğitimine Yönelik Görüşv ve Politikalartn İncelenmesi. Doktora Tezi, Marmara Üniversitesi Eğitim Bilimleri Enstitüsü.

Merriam, S. B. (1998). Qualitative Research and Case Study Applications in Education. Revised and Expanded from. Jossey-Bass Publishers, 350 Sansome St.

Merriam, S. B. (2009). Qualitative research: A guide to design and implementation (Revised and expanded from qualitative research and case study applications in education). John Wiley $\&$ Sons, Inc.

Metin, M. (2014). Kuramdan uygulamaya eğitimde bilimsel araştırma yöntemleri.Pegem Akademi Yayınları.

Onural, H. (2005). Üst düzey eğitim yöneticilerinin eğitim yönetimi alanındaki yeterlik sorunu ve nedenleri. Kuram ve Uygulamada Ĕ̈itim Yönetimi, 41(41), 69-85.

Özcan, H. ve Koştur, H. İ. (2019). Ortaokul öğretmenlerinin TIMMS sınavına ilişkin görüşlerinin incelenmesi. Eğitimde Kuram ve Uygulama, 15(2), 108-120.

Özdemir, M. (2009). Okul yöneticiliğinin hukuksal temelleri. Ankara Üniversitesi Ĕ̆itim Bilimleri Fakültesi, 42 (2), 279-300.

Özsoy, S. (2012). Eğitimi politik düşün(eme)mek üzerine bir örnek olay incelemesi: 4x3'lük zorunlu eğitim tartışmaları. Ĕgitim Bilim Toplum, 10(96).

Patton, M. Q. (2002). Qualitative research \& evaluation methods. (3rd ed.). Thousand Oaks, SAGE Publications, Inc.

Safran, M., Kan, A., Üstündağ, M. T., Birbudak, T. S. ve Yıldırım, O. (2014). 2013 KPSS sonuçlarının öğretmen adaylarının mezun oldukları alanlara göre incelenmesi. Eğitim ve Bilim, 39(171).

Silverman, D. (2013). Doing Qualitative Research: A Practical Handbook. Sage.

Şahin, İ. (2011). Öğretmen adaylarının öğretmen istihdamı ve mesleki geleceklerine ilişkin görüşleri. Kuram ve Uygulamada Eğitim Bilimleri, 11(3), 1167-1184. 
Şişman, M. (2012). Eğitim bilimine giriş (10. Baskı). Pegem A Yayınları.

Terzi Ç. (2005). Uyum sürecinde Türkiye eğitim politikalarının Avrupa Birliği politikaları doğrultusunda değerlendirilmesi. Yayınlanmış doktora tezi, Anadolu Üniversitesi Eğitim Bilimleri Enstitüsü.

Tuzcu, G. (2002). Avrupa Birliğine geçiş sürecinde Türk eğitiminin planlanması. Milli Eğitim Dergisi, s.155-156.

Yapıc1, M. (2006). Eğitim politikası. Üniversite ve Toplum Dergisi, Haziran, 6 (2).

Yazıc1, H. (2009). Öğretmenlik mesleği, motivasyon kaynakları ve temel tutumlar: kurumsal bir bakış. Kastamonu Eğitim Dergisi, 17(1), 33-46.

Yıldırım, A. (2011). Öğretmen eğitiminde çatışma alanları ve yeniden yapılanma. Uluslararası Ĕ̈itim Programları ve Öğretim Çalışmaları Dergisi, 1(1), 1-17.

Yıldırım, A. ve Şimşek, H. (2013). Sosyal bilimlerde nitel araştırma yöntemleri (9.Baskı). Seçkin Yayıncilik.

Yıldırım, K. (2009). Uluslararası ögrenci değerlendirme programı (PISA) 2006 yılı verilerine göre Türkiye'de eğitimin kalitesini belirleyen temel faktörler. Yayımlanmamış doktora tezi, Gazi Üniversitesi Eğitim Bilimleri Enstitüsü.

Yılmaz, B. (2004). Türkiye'de eğitim politikası ve kütüphane. Bilim ve Ütopya, 139.

Yılmaz, G. K., Koparan, T. ve Hanc1, A. (2016). 8. Sınıf öğrencilerinin öğrenme stilleri ve TIMMS matematik başarıları arasındaki ilişkinin belirlenmesi. Bayburt Üniversitesi Eğitim Fakültesi Dergisi, 11(1), 36-58. 